Kennoki Kyo - Tetsuichiro Muto • Hirokazu Nagawa

G. Mark Lathrop • Yusuke Nakamura

\title{
Associations of distinct variants of the intestinal mucin gene MUC3A with ulcerative colitis and Crohn's disease
}

Received: September 28, 2000 / Accepted: October 13, 2000

\begin{abstract}
Ulcerative colitis (UC) and Crohn's disease (CD), the major forms of inflammatory bowel diseases (IBDs), are multifactorial disorders of unknown etiology. We reported a possible association of rare variable number of tandem repeat (VNTR) alleles of the "MUC3" gene with a susceptibility to UC. However, an entire structure of "MUC3" is still unknown because the long stretches of tandem repeats in this "gene" make its cloning extraordinarily difficult. In this study, we report evidence that "MUC3" consists of two genes, $M U C 3 A$ and $M U C 3 B$, both of which encode membrane-bound mucins with two epidermal growth factor-like motifs, and we describe the complete 3 '-terminal structures of these two genes. We have also analyzed the single nucleotide polymorphisms (SNPs) in the exonic sequences of the 3' portions of these two genes to investigate whether sequence variations in these regions can cause person-to-person differences in the susceptibility to IBDs, and report here that non-synonymous SNPs of $M U C 3 A$, involving a tyrosine residue with a proposed role in cell signaling, may confer genetic predisposition to $\mathrm{CD}$ $(P=0.0132)$. Our findings suggest that variants of $M U C 3 A$ may be involved in the occurrence of UC and CD in distinct manners.
\end{abstract}

Key words $M U C 3 A \cdot M U C 3 B \cdot$ Ulcerative colitis · Crohn's disease $\cdot$ VNTR $\cdot$ SNP

K. Kyo · Y. Nakamura $(\square)$

Laboratory of Molecular Medicine, Human Genome Center,

Institute of Medical Science, The University of Tokyo, 4-6-1

Shirokanedai, Minato-ku, Tokyo 108-8639, Japan

Tel. +81-3-5449-5372; Fax +81-3-5449-5433

e-mail: yusuke@ims.u-tokyo.ac.jp

K. Kyo $\cdot$ T. Muto $\cdot$ H. Nagawa

Department of Surgical Oncology, The University of Tokyo, Tokyo, Japan

G.M. Lathrop

Centre National de Genotypage, Evry, France

\section{Introduction}

Ulcerative colitis (UC) and Crohn's disease (CD) are the major forms of inflammatory bowel diseases (IBDs). The etiology remains unknown, but it is currently accepted from the familial aggregation of IBD patients (Orholm et al. 1991) and from the increased yet incomplete concordance rates in monozygotic versus dizygotic twins (Tysk et al. 1988) that both environmental and genetic factors interact in the occurrence of these disorders. As for genetic factors, linkage analysis for susceptibility genes in IBDs involving 186 affected sibling pairs showed evidence for linkage to markers D12S83, D7S669, and D3S1573 with logarithm of odds (lod) scores of 5.47, 3.08, and 2.69, respectively (Satsangi et al. 1996). The fact that the marker D7S669 is located near the human intestinal mucin gene "MUC3" and previous reports that indicated a possible mucin abnormality in IBD patients (Buisine et al. 1999; Tysk et al. 1991) prompted us to examine a correlation between "MUC3" and IBDs. Genotying of variable number of tandem repeat (VNTR) in the "MUC3" gene implied that rare alleles of "MUC3", which have an unusual number of 51-bp repeat units, are associated with the risk of UC (Kyo et al. 1999).

Mucins are large and heterogeneous glycoproteins subdivided into membrane-bound and soluble forms. They have important roles not only in the protection of epithelium, but in the adhesion and growth of epithelial cells, signal transduction, and modulation of immune system (Agrawal et al. 1998a; Agrawal et al. 1998b; Carraway et al. 1999). Each of the known mucin genes contains in its coding region a long stretch of repeated sequences. "MUC3" contains two separate regions of 51-bp tandem repeats, each covering several kilobases, and in one of their upstream regions lies a 177-bp repeat with the intervention of $810 \mathrm{bp}$ of a semi-unique coding region (van Klinken et al. 1997), and in the other lies a 1125-bp repeat without intervention of any other exon or intron sequences (Gum et al. 1997), and both repeats also cover several kilobases. The long stretches of tandem repeats of "MUC3" make its cloning extraordinarily difficult, and the entire structure of 
"MUC3" is still unknown, although 10 years have passed since the sequences of short partial cDNA clones of "MUC3" were first reported (Gum et al. 1990).

The sequence of the $3^{\prime}$ region of "MUC3" was once reported, which indicated that "MUC3" was a secretory mucin with one epidermal growth factor (EGF)-like domain (Gum et al. 1997). We could not explain the dominant effect observed in the association study we reported recently (Kyo et al. 1999), because human MUC3 was considered to be a secretory mucin and mucin protein encoded by a common allele would compensate for the function of that encoded by a rare allele. Furthermore, it has been unknown whether the 51-bp repetitive regions lie in a single gene, making an internal duplication, or whether they lie in two tandemly arrayed genes (Gum et al. 1997). We reanalyzed the 3' terminal structure of "MUC3", and here we demonstrate that "MUC3" consists of two genes, MUC3A and $M U C 3 B$, each of which possesses two EGF-like domains and a putative transmembrane region, and we again discuss the implication of the association of rare alleles of $M U C 3 \mathrm{~A}$ with UC.

Single nucleotide polymorphisms (SNPs) have a great potential for application to association studies with diseases and pharmacogenetic traits (Chakravarti 1999; Housman and Ledley 1998), and SNPs in coding regions (cSNPs), particularly those that alter amino acid sequences of the encoded proteins, are most likely to influence the protein function and thus be involved in complex human diseases (Chakravarti 1999; Cargill et al. 1999). We identified and analyzed SNPs in the exonic sequences of the $3^{\prime}$ regions of these two genes for the association with IBDs, and have found that non-synonymous SNPs of MUC3A involving a tyrosine residue with a proposed role in cell signaling may be involved in the person-to-person differences in the susceptibility to $\mathrm{CD}$. Thus, we report here that distinct variants of $M U C 3 A$ may be involved in the occurrence of $\mathrm{UC}$ and $\mathrm{CD}$.

\section{Materials and methods}

\section{Southern blot analysis}

Five micrograms of genomic DNA were digested to completion with restriction enzyme $P v u l l$ (Toyobo, Tokyo, Japan), run in $0.5 \%$ agarose gel ( $13 \mathrm{~cm}$ long) at $25 \mathrm{~V}$ for $48 \mathrm{~h}$ and transferred to a nylon membrane, as described previously (Kyo et al. 1999). Blots were proved with a clone composed of a 51-bp repeat (51R), a 498-bp clone corresponding to a part of 1125-bp repeat unit located between Pvull-restriction site and 51-bp repeat (1125D), a 796-bp clone corresponding to a semi-unique region located between the 177-bp repeat and the 51-bp repeat (SUR), or three distinct parts of the $3^{\prime}$ region of "MUC3", the sequence of which Gum et al. (1997) reported previously (3TR-1, 3TR-2, or 3TR-3; Fig. 1b). Clone 51R was prepared as described (Kyo et al. 1999), and clone 1125D was prepared by PCR amplification, using primers 1125DF and
1125DR (Table 1); the PCR reaction consisted of one cycle of denaturation at $95^{\circ} \mathrm{C}$ for $5 \mathrm{~min}, 35$ cycles of denaturation at $94^{\circ} \mathrm{C}$ for $30 \mathrm{~s}$, annealing at $57^{\circ} \mathrm{C}$ for $30 \mathrm{~s}$, and extension at $72^{\circ} \mathrm{C}$ for $30 \mathrm{~s}$. Clone SUR was also prepared likewise, using primers SUR-F and SUR-R (Table 1); the PCR regime included one cycle of $95^{\circ} \mathrm{C}$ for $5 \mathrm{~min}, 35$ cycles of $94^{\circ} \mathrm{C}$ for $30 \mathrm{~s}, 57^{\circ} \mathrm{C}$ for $30 \mathrm{~s}$, and $72^{\circ} \mathrm{C}$ for $1 \mathrm{~min}$. Clones $3 \mathrm{TR}-1$ to -3 were prepared by PCR, using primer sets $3 \mathrm{TR}-1 \mathrm{~F} / 3 \mathrm{TR}-1 \mathrm{R}$, 3TR-2F/3TR-2R, and 3TR-3F/3TR-3R (Table 1), respectively, which were constructed on the basis of the reported sequence (Gum et al. 1997); the PCR regime included one cycle of $95^{\circ} \mathrm{C}$ for $5 \mathrm{~min}, 35$ cycles of $94^{\circ} \mathrm{C}$ for $30 \mathrm{~s}, 57^{\circ} \mathrm{C}$ for 30 s for 3 TR- 1 and 3 TR $-3\left(55^{\circ} \mathrm{C}\right.$ for 30 s for 3 TR-2), and $72^{\circ} \mathrm{C}$ for $1 \mathrm{~min}$ for $3 \mathrm{TR}-1$ (for $30 \mathrm{~s}$ for $3 \mathrm{TR}-2$ and $3 \mathrm{TR}-3$ ). Each of the PCR reaction mixtures was prepared in $30 \mu$ l of reaction volume containing $20 \mathrm{ng}$ of genomic DNA, $3 \mu \mathrm{l}$ of $10 \times$ PCR buffer [ $\left[166 \mathrm{mM}(\mathrm{NH} 4)_{2} \mathrm{SO}_{4}, 670 \mathrm{mM}\right.$ Tris (pH8.8), $20 \mathrm{mM} \mathrm{MgCl}_{2}, 100 \mathrm{mM} \beta-\mathrm{MeEtOH}, 67 \mu \mathrm{M}$ ethylenediamine tetraacetic acid (EDTA)], 1.5 U of Ex Taq polymerase (TaKaRa, Tokyo, Japan), 20 pmol of each primer, $1.5 \mathrm{mM}$ dNTPs, $4.7 \mathrm{mM} \mathrm{MgCl} 2$, and $10 \%$ dimethylsulfoxide (DMSO). These clones were confirmed by sequencing and were labeled by the random priming method, using a Megaprime DNA labeling system (Amersham, Buckinghamshire, UK) according to the manufacturer's instructions. The hybridization and washing of the blots were carried out as described (Kyo et al. 1999).

\section{Sequence analysis}

As demonstrated in Fig. 1a, two sets of bands were observed in the Southern analysis when Pvull-digested genomic DNA fragments were hybridized with the clone 51R as a probe. The larger set of hybridizing bands was 20 to $40 \mathrm{~kb}$ in size, and the smaller set was 10 to $15 \mathrm{~kb}$. These bands were also detected with clones 3TR-1 to -3, suggesting that the $3^{\prime}$ regions of these two genes share high homology with each other. We hypothesized, because of the reason, noted in the "Discussion" section, that these sets of hybridizing bands were derived from distinct genes, and we designated, as recommended by the Human Gene Nomenclature Committee, the genes which contained smaller and larger sets of hybridizing bands as $M U C 3 A$ and $M U C 3 B$ genes, respectively.

$P v u l l-d i g e s t e d$ genomic DNA fragments were separated in the $0.5 \%$ agarose gel $(25 \mathrm{~cm}$ long), run at $40 \mathrm{~V}$ for $72 \mathrm{~h}$, and fragments from 20 to $40 \mathrm{~kb}$ in size and those from 10 to $15 \mathrm{~kb}$ were cut out and purified, and were utilized as templates for PCR amplifications, using common primers 3TR1F and 3TR-3R (1A and 1B in Fig. 1b; Table 1). The PCR reaction mixtures were prepared as mentioned above, and the reactions consisted of one cycle of $95^{\circ} \mathrm{C}$ for $5 \mathrm{~min}$ followed by 32 cycles of $94^{\circ} \mathrm{C}$ for $30 \mathrm{~s}, 57^{\circ} \mathrm{C}$ for $30 \mathrm{~s}$, and $72^{\circ} \mathrm{C}$ for $3 \mathrm{~min}$. Each of the amplified products was directly sequenced on both strands with an ABI 377 Autosequencer (Perkin-Elmer, Norwalk, CT, USA). A genomic DNA sample from the same person was utilized for the following analysis of the genomic structures of these two genes. 
a

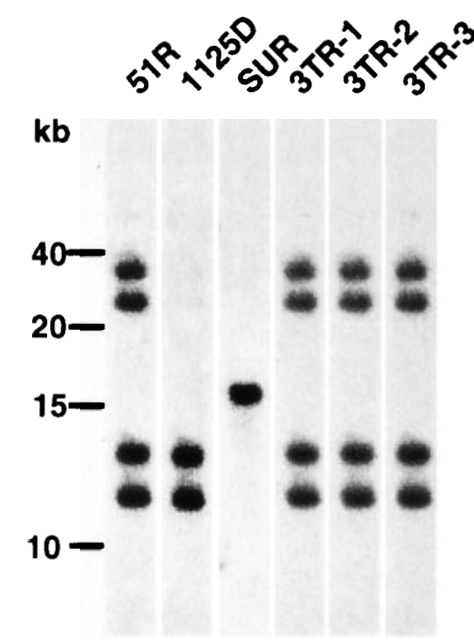

b

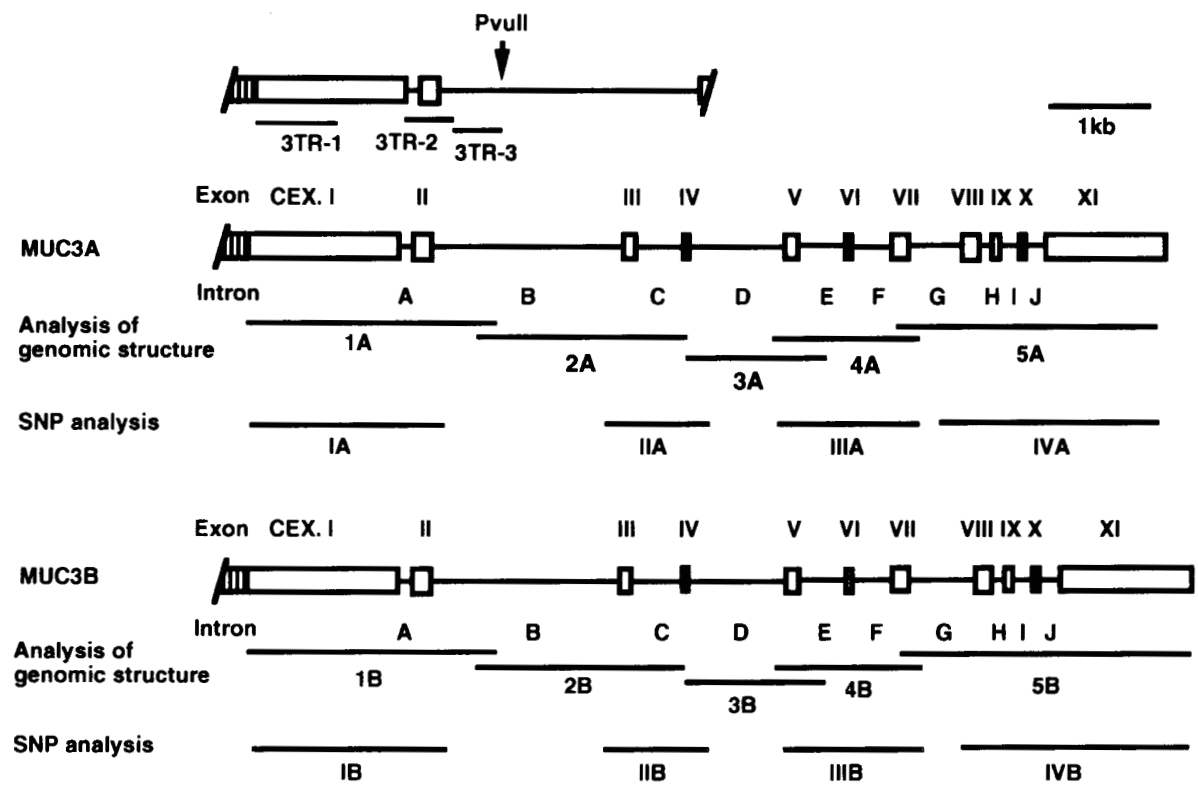

\section{C}

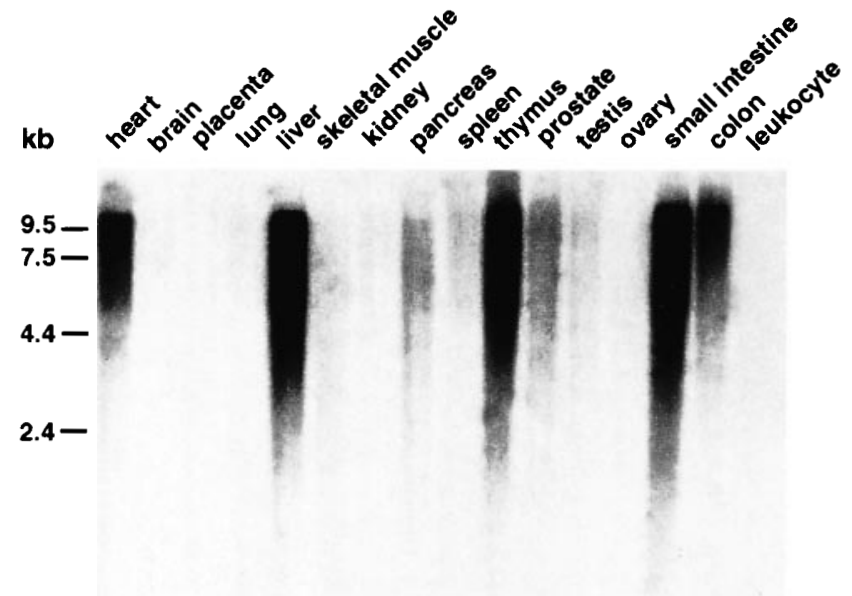

Fig. 1a-d. Genomic structures of the $3^{\prime}$ regions and tissue expressions of $M U C 3 A$ and $B$. a Autoradiographs of Southern blots showing hybridization with clones 51R, 1125D, SUR, 3TR-1, 3TR-2, or 3TR-3. Pvull-digested genomic DNA fragments $(5 \mu \mathrm{g})$ were size-fractionated on a $0.5 \%$ agarose gel and transferred to a nylon membrane prior to hybridization. The positions of clones 3TR-1, 3TR-2, and 3TR-3 are demonstrated in $\mathbf{b}$. b Upper molecule; schematic representation of the genomic structure once reported as the 3' region of "MUC3" (Gum et al. 1997). The sequences of CEX.III (see below) were included in an intronic sequence. The positions of clones 3TR-1, 3TR-2, and 3TR-3, which were used as probes in the Southern analysis, are indicated with bars below the figure. The Pvull-restriction site is shown with an arrow. b Middle and lower molecules; schematic overview of the genomic

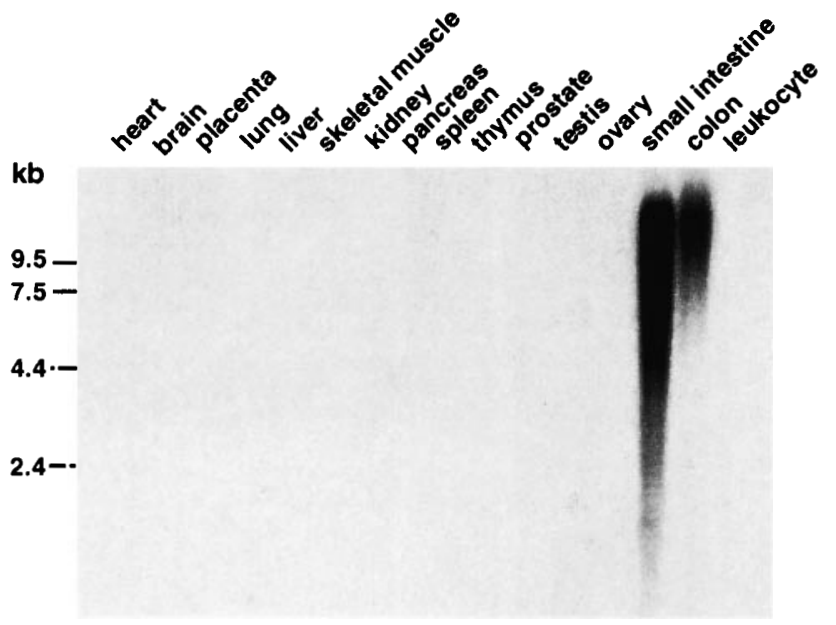

structures of the $3^{\prime}$ region of $M U C 3 A$ (middle molecule) and MUC3B (lower molecule). Exons and introns are indicated by boxes and lines, respectively. Boxes with vertical hatching indicate the 51-bp repeat. Exons in the $3^{\prime}$ region of each gene are numbered consecutively as CEX. I to XI above the boxes. Introns are named below the lines in capital letters. The positions of clones obtained by polymerase chain reaction (PCR) amplifications in the analyses of genomic structures (1A-5A for $M U C 3 A$ and $1 \mathrm{~B}-5 \mathrm{~B}$ for $M U C 3 B$ ) and in the identification of single nucleotide polymorphisms (SNPs) (IA-IVA for MUC3A and IB-IVB for $M U C 3 B)$ are indicated with bars below the figures. c, d Northern blot analyses of $M U C 3 A$ (c) and $M U C 3 B$ (d) genes. RNA blots containing $2 \mu \mathrm{g}$ of poly $\mathrm{A}^{+} \mathrm{RNA}$ from each of 16 human tissues were hybridized with clones $1125 \mathrm{D}$ for $M U C 3 A$ or $117 \mathrm{R}$ for $M U C 3 B$ 
Table 1. Sequence of PCR primers

\begin{tabular}{|c|c|c|c|}
\hline \multicolumn{4}{|c|}{ Southern analysis } \\
\hline 1125DF & GAATCCACСССАТСАССТАC & 1125DR & GGTGGAATAGGTGGTTCTGG \\
\hline SUR-F & GTACCACACCTGTTACGAGG & SUR-R & GATGCAGAAGTAGTGCAGCC \\
\hline 3TR-1F & TCAACATCTACTCCACAGTC & 3TR-1R & GAAGAAGGAACAGAATGAATGG \\
\hline $3 \mathrm{TR}-2 \mathrm{~F}$ & TCTGTTCCCCTCCTTCCTC & 3TR-2R & GGAGAGGAGCATGACACAG \\
\hline 3TR-3F & CTCCGTCCTCACCCTTAGG & 3TR-3R & CTGATCTTGAGAAAATTAACATAG \\
\hline \multicolumn{4}{|l|}{ 3"RACE } \\
\hline \multicolumn{4}{|c|}{ 1) $M U C 3 A$} \\
\hline A-1 & CTGAGCAACAGTTCTGTGATCCCCCT & AN-1 & CGCAGGACAACTCGCATCACTTCTCA \\
\hline A-2 & CGGGCTATGAAGAGTTCTACTTCCССТ & AN-2 & GCTGTGTCACCAAATGCACGTCTGGG \\
\hline A-3 & GAATCTTGGGCAAGTCAGTAACGAGCC & AN-3 & GCATTCCTGTATGATAGCTCACGCCG \\
\hline A-4 & CACCCTGCTGCCCAATTCTTTATTC & AN-4 & ТTТСТСТСАССССТGGAGCССТGC \\
\hline \multicolumn{4}{|c|}{ 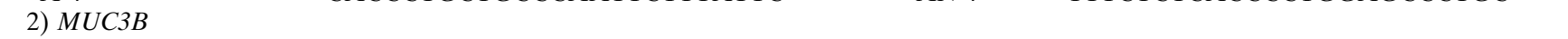 } \\
\hline B-1 & CTGAGCAACAACTCTGTGATCCCCAC & $\mathrm{BN}-1$ & CGCAGGACAACTCCCATCACTTCTTG \\
\hline B-2 & CGGGCTATGAAGAGTTCTACTTCCCTC & $\mathrm{BN}-2$ & GCTGTGTCACCAAATGCACGTCGGGC \\
\hline B-4 & CCAGCCACCGGATTCTCCATTCAC & $\mathrm{BN}-4$ & TTTCTCTCACCCCTGGAGCCCCGT \\
\hline \multicolumn{4}{|c|}{ 3) Linearity check } \\
\hline AF1 & AGACCTGGCTGAGCAACAGT & BF1 & AGACCTGGCTGAGCAACAAC \\
\hline RPR-1 & CAGGGTCATGGGGGGAAC & RPR-2 & ACGGGGTGAGGGGGGAATT \\
\hline \multicolumn{4}{|c|}{ RT-PCR analysis of splicing variants } \\
\hline ABR1 & ACTGAGGACGAGGTCATCTC & & \\
\hline \multicolumn{4}{|c|}{ Analysis of genomic structures } \\
\hline AF2 & TGGAGCCTCCCACAGCAAG & BF2 & ССАТСТTCСАAGCCAGCAAG \\
\hline ABR2 & AAGGTGAAGCCCTGCATGTC & ABF1 & TGGAGATCCTGTCCCTGAG \\
\hline AR1 & TAGCCCCACCCTTGGCAC & BR1 & CTAGCCCCACTCTTGATGG \\
\hline AF3 & CCTCCAAGGACCCATATGTT & BF3 & CTCCAAGGACCCATGTGCC \\
\hline AR2 & GTCGATGGCGTTGTCCACC & BR2 & GTCGATGGCGTTGTCCACG \\
\hline AF4 & TCACCAAATGCACGTCTGGG & $\mathrm{BF} 4$ & CACCAAATGCACGTCGGGC \\
\hline ABR3 & TCCTGTCCCCAAAGCCAATC & & \\
\hline \multicolumn{4}{|c|}{ Northern analysis } \\
\hline $117 \mathrm{RF}$ & TCTCAGTACCACGCCGGTG & 177RR & AGGCATAATGGTTAATGGAGTG \\
\hline \multicolumn{4}{|c|}{ SNP identification } \\
\hline \multicolumn{4}{|c|}{ 1) $M U C 3 A$} \\
\hline AF5 & САTCTACTCCACAGTCAGCA & ABR4 & CCCACAGAGGGATAAGTCTG \\
\hline AF6 & CTCAGCCTCCTGAGGCATA & ABR5 & GGGAGTGATTCCTTATGTACC \\
\hline AR3 & GGCGGAGCATGGGGCAG & AF7 & GTTCTAGGGTGGATTCCCAG \\
\hline AR4 & CAATCTTCCCCGCCAAGGC & & \\
\hline \multicolumn{4}{|c|}{ 2) $M U C 3 B$} \\
\hline BF5 & GGGTGACTTCCACACСТTC & BF6 & CTCAGCCTCCCAAGGCACT \\
\hline BR3 & GGCGGCGCGTGAGGCTA & BF7 & TTCTACGGTGGATTCCGGC \\
\hline BR4 & CAATCTTCCCCGCCAAGGA & & \\
\hline \multicolumn{4}{|c|}{ 3) Association analysis } \\
\hline AF8 & ССТТСАААСААСТССТССТАСТ & ABR6 & TTATAGTTCCTGGACAGGGTG \\
\hline AF9 & CTGCAACTACCAGCACTTCTT & AR5 & GAACTGGAAGCATTGGGTGA \\
\hline ABR7 & CCAGAGGTACCACAGGGCT & ABF2 & CGGAAATGGAATCCТССТCG \\
\hline
\end{tabular}

PCR, Polymerase chain reaction; RACE, rapid amplification of cDNA ends; RT, reverse transcription; SNP, single nucleotide polymorphism

3' Rapid amplification of cDNA ends (RACE)

The sequence differences observed in the two PCRamplified products mentioned above enabled us to construct RACE primers specific to each gene. Four rounds of RACE reactions were conducted for each of the $M U C 3 A$ and $M U C 3 B$ genes to reach the poly (A) tail, using a Marathon cDNA amplification kit and Marathon-Ready cDNA from adult small intestine (both from Clontech, Palo Alto, CA, USA). Gene specific primers A-1 to -4 for the $M U C 3 A$ sequence and $\mathrm{B}-1,-2$, and -4 for the $M U C 3 B$ sequence were used for primary amplifications, and $\mathrm{AN}-1$ to -4 and $\mathrm{BN}-1,-2$ and -4 were used as gene-specific nested primers (Table 1). The primers used for the first round of RACE reactions were constructed on CEX. I (Fig. 1b). In the third round of RACE amplifications, common primers A-3 and AN-3 were used for both $M U C 3 A$ and $M U C 3 B$, because no sequence difference was found between the second round of amplified products of $M U C 3 A$ and $M U C 3 B$. Because two distinct sequences with a high degree of similarity were obtained in the third round of amplifications, each linearity was checked by PCR, using primers $\mathrm{AF} 1$ for $M U C 3 A$ and $\mathrm{BF} 1$ for $M U C 3 B$, and primers RPR-1 and RPR-2, which were constructed on the amplified products of the third-round reactions (Table 1).

For the RACE reactions, we used a Perkin-Elmer Thermal Cycler Gene Amp PCR System 9700, and each of the primary reactions consisted of denaturation at $94^{\circ} \mathrm{C}$ for $30 \mathrm{~s}$, followed by five cycles of denaturation at $94^{\circ} \mathrm{C}$ for $10 \mathrm{~s}$, annealing and extension at $72^{\circ} \mathrm{C}$ for $4 \mathrm{~min}$, with five subsequent cycles of $94^{\circ} \mathrm{C}$ for $10 \mathrm{~s}$ and $70^{\circ} \mathrm{C}$ for $4 \mathrm{~min}$, followed by 25 remaining cycles of $94^{\circ} \mathrm{C}$ for $10 \mathrm{~s}$ and $68^{\circ} \mathrm{C}$ for $4 \mathrm{~min}$. Each of the nested-PCR reactions consisted of one cycle of $94^{\circ} \mathrm{C}$ for $30 \mathrm{~s}$ followed by five cycles of $94^{\circ} \mathrm{C}$ for $10 \mathrm{~s}$ and $72^{\circ} \mathrm{C}$ for $4 \mathrm{~min}$, with five subsequent cycles of $94^{\circ} \mathrm{C}$ for $10 \mathrm{~s}$ and $70^{\circ} \mathrm{C}$ for $4 \mathrm{~min}$, followed by 20 remaining cycles of $94^{\circ} \mathrm{C}$ for $10 \mathrm{~s}$ and $68^{\circ} \mathrm{C}$ for $4 \mathrm{~min}$. 
After the amplified products were electrophoresed on agarose gels, bands were cut out, cloned into pBluescript II SK(-) and sequenced on both strands with an ABI 377 Autosequencer (Perkin-Elmer). At least five clones for each were sequenced for comparison between the MUC3A and $M U C 3 B$ sequences.

Reverse transcription (RT)-PCR analyses of splicing variants

One microgram of poly $\mathrm{A}^{+} \mathrm{RNA}$ isolated from small intestine (Clontech) was reverse-transcribed, using an oligodT17 primer (Boehringer Mannheim, Mannheim, Germany) and Superscript II RNase $\mathrm{H}^{-}$reverse transcriptase (GIBCO BRL, Rockville, MD, USA). The resultant cDNA product was amplified by PCR, using primer sets AF1/ABR1 for $M U C 3 A$ and BF1/ABR1 for $M U C 3 B$ (Table 1). These primers were constructed on CEX. I and CEX. XI of $M U C 3 A$ and $M U C 3 B$ (Fig. 2b,c). The PCR reaction mixtures were prepared as mentioned above, and the PCR regime included one cycle of $95^{\circ} \mathrm{C}$ for $5 \mathrm{~min}$, then 32 cycles of $94^{\circ} \mathrm{C}$ for $30 \mathrm{~s}, 55^{\circ} \mathrm{C}$ for $30 \mathrm{~s}$, and $72^{\circ} \mathrm{C}$ for $2 \mathrm{~min}$. The PCR products were separated on an agarose gel and all visible bands were cut out and cloned into pBluescript II SK(-), and sequenced on both strands with an ABI 377 Autosequencer (Perkin-Elmer).

Analyses of genomic structures of the $3^{\prime}$ regions of $M U C 3 A$ and $M U C 3 B$ genes

Genomic structures of the $3^{\prime}$ regions of the $M U C 3 A$ and $M U C 3 B$ genes were analyzed by PCR amplifications conducted in five overlapping regions (Fig. 1b). Region 1 of each gene (1A and $1 \mathrm{~B}$ ) was amplified by PCR using primers 3TR-1F and 3TR-3R (Table 1), as mentioned above. For the amplifications of regions 2 to 5, primer sets of AF2/ ABR2, ABF1/AR1, AF3/AR2, AF4/ABR3 for MUC3A ( $2 \mathrm{~A}$ to $5 \mathrm{~A}$ ), and $\mathrm{BF} 2 / \mathrm{ABR} 2, \mathrm{ABF} 1 / \mathrm{BR} 1, \mathrm{BF} 3 / \mathrm{BR} 2$, and $\mathrm{BF} 4 / \mathrm{ABR} 3$ for $M U C 3 B$ (2B to $5 \mathrm{~B}$ ) were used (Table 1). Each of the reactions consisted of denaturation at $95^{\circ} \mathrm{C}$ for $5 \mathrm{~min}$ followed by 32 cycles of denaturation at $94^{\circ} \mathrm{C}$ for $30 \mathrm{~s}$, annealing at $55^{\circ} \mathrm{C}$ for $30 \mathrm{~s}$ for regions $3 \mathrm{~A}, 3 \mathrm{~B}$, and $4 \mathrm{~A}$ or at $57^{\circ} \mathrm{C}$ for $30 \mathrm{~s}$ for all others, and extension at $72^{\circ} \mathrm{C}$ for $2 \mathrm{~min}$. The amplified products were cloned into pBluescript II SK $(-)$, and at least five clones were sequenced for each, in both directions, with the ABI 377 Autosequencer (PerkinElmer). The position, size, and sequence of the introns were confirmed by comparison of PCR-amplified products of genomic DNA with products of RT-PCR mentioned above.

Comparison of sequences to databases and examination of amino acid sequences for potential structural domains were performed using the BLAST, FASTA, and MOTIF programs accessed through the Human Genome Center, Institute of Medical Science, University of Tokyo (http:/ www.genome.ad.jp/), and ExPASy sequence analysis programs (http:/www.expasy.ch/). The genomic sequences of the $3^{\prime}$ regions have been submitted to the GenBank database with accession numbers AB038782 for MUC3A and AB038781 for $M U C 3 B$. The cDNA sequences of the major transcripts have also been submitted, with accession numbers AB038784 for $M U C 3 A$ and AB038783 for $M U C 3 B$.

\section{Northern blotting analysis}

Multiple-tissue Northern blots (Clontech) containing $2 \mu \mathrm{g}$ of poly $\mathrm{A}^{+}$RNAs from heart, brain, placenta, lung, liver, skeletal muscle, kidney, pancreas, spleen, thymus, prostate, testis, ovary, small intestine, colon, and leukocyte were used for analysis. Clone 1125D and a 532-bp clone 177R, composed of a 177-bp repeat, were used to investigate the expression of MUC3A and MUC3B. Clone 177R was prepared by cloning into pBluescript II SK(-) the PCR products amplified with primers 177RF and 177RR (Table 1). The PCR utilized genomic DNA as a template, and consisted of $95^{\circ} \mathrm{C}$ for $5 \mathrm{~min}$, followed by 32 cycles of $94^{\circ} \mathrm{C}$ for $30 \mathrm{~s}, 57^{\circ} \mathrm{C}$ for $30 \mathrm{~s}$, and $72^{\circ} \mathrm{C}$ for $30 \mathrm{~s}$. Probes were labeled with $\left[\alpha-{ }^{32} \mathrm{P}\right] \mathrm{dCTP}$, using the Megaprime DNA labeling system (Amersham). Hybridization and washing of the blots were performed as per the manufacturer's instructions.

Identification and association analysis of SNPs

To investigate whether some sequence variations contribute to the susceptibility to IBDs, we screened genomic DNA samples isolated from 30 patients with UC and 30 with $\mathrm{CD}$, and surveyed the exon sequences of the $3^{\prime}$ regions of $M U C 3 A$ and $M U C 3 B$. These sequences were amplified by PCR, using gene-specific primer sets AF5/ABR4 (for IA), AF6/ABR5 (IIA), AF3/AR3 (IIIA), and AF7/AR4 (IVA) for $M U C 3 A$, and BF5/ABR4 (IB), BF6/ABR5 (IIB), $\mathrm{BF} 3 / \mathrm{BR} 3$ (IIIB) and BF7/BR4 (IVB) for MUC3B (Fig. 1b, Table 1). The reaction consisted of $95^{\circ} \mathrm{C}$ for $5 \mathrm{~min}$ followed by 35 cycles of $94^{\circ} \mathrm{C}$ for $30 \mathrm{~s}$ and $57^{\circ} \mathrm{C}$ for $30 \mathrm{~s}$ for IVA and IIB $\left(55^{\circ} \mathrm{C}\right.$ for 30 s for all others) and $72^{\circ} \mathrm{C}$ for $1 \mathrm{~min}$ for IIA and IIB $\left(72^{\circ} \mathrm{C}\right.$ for $2 \mathrm{~min}$ for all others). The amplified products were directly sequenced by mixing three samples in one with an ABI 3700 Autosequencer (Perkin-Elmer) in both directions, and SNPs were identified using a combination of the PolyPhred program (Nickerson et al. 1997) followed by visual inspection.

For each of the identified SNPs, 72 sporadic cases of UC and 70 unrelated patients with $C D$, as well as ethnically matched controls, were genotyped by PCR amplifications, using primers specific to each gene, followed by allelespecific oligonucleotide hybridization (ASO), except for nucleotide (nt) 3337 to 3398 of MUC3A and nt 155 to 270 and 3141 to 3469 of $M U C 3 B$ (Table 2), where genotyping was done by sequencing because the close proximity between SNP sites makes hybridization difficult. Details of the UC patients and controls were described previously (Kyo et al. 1999). The total of $70 \mathrm{CD}$ patients consisted of $44 \mathrm{spo}-$ radic $C D$ cases, with the remaining 26 patients being the younger brothers or sisters of $\mathrm{CD}$-affected siblings. Sporadic CD cases were ascertained through the Department of Surgical Oncology, the University of Tokyo, or through the Second Department of Surgery, School of Medicine, Hamamatsu University. CD-Affected siblings were 
a

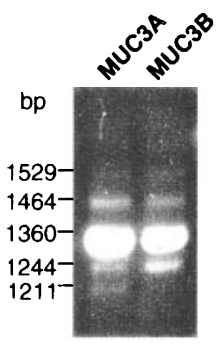

C

мUс3в

CEX.I ॥

III IV

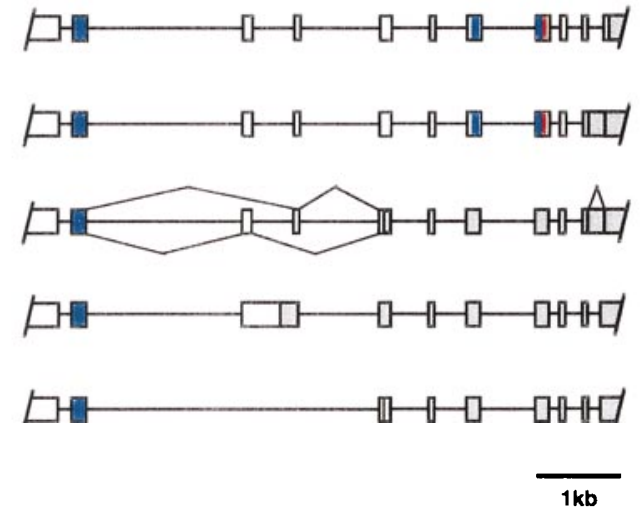

b MUC3A

CEX. I "

III IV

V VI VII VIII IX XXI

Size of amplified products (bp)

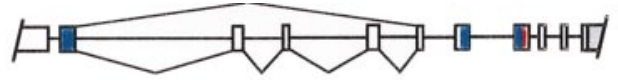

1030

1360

1529

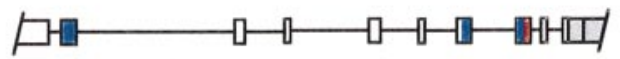

* 1179

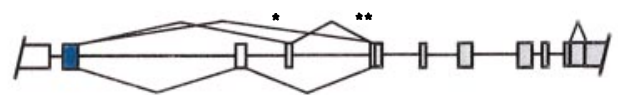

** 1244

1464

1211

Size of amplified products (bp)

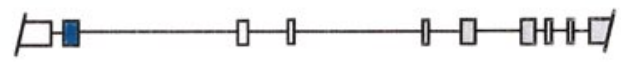

1360

맘마마미

1631

口П

1533

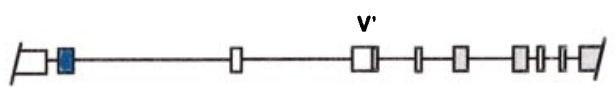

1468

1464

1779

1179

XII

口다료 1453

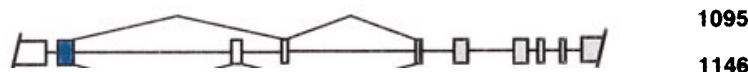

1146

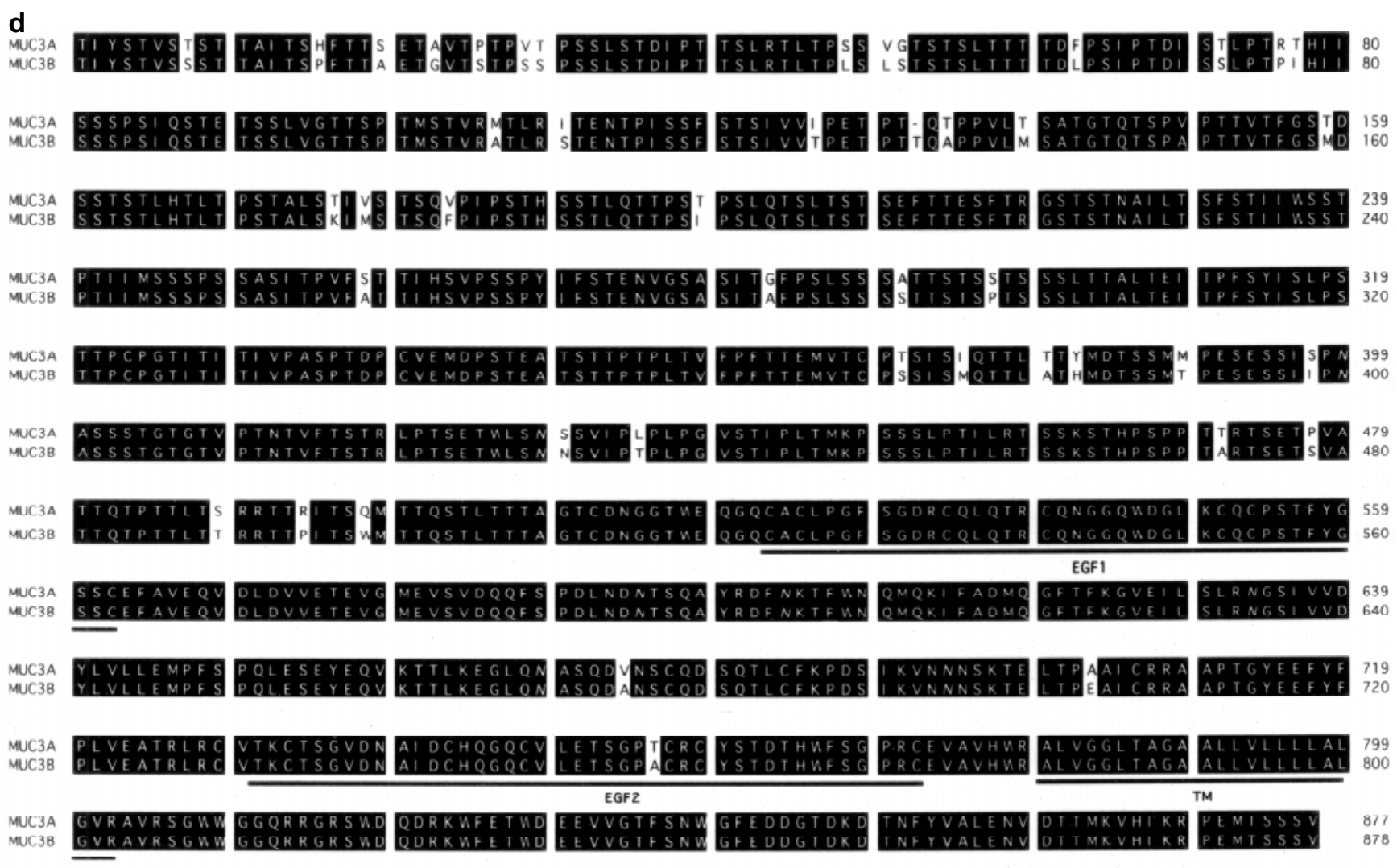

Fig. 2a-c. Reverse transcription-polymerase chain reaction (RT-PCR) analyses of splicing variants. a RT-PCR amplifications of transcripts of $M U C 3 A$ and $M U C 3 B$. Gene-specific primers used for the amplifications were constructed on CEX. I and XI of each gene. b, $\mathbf{c}$ Schemes depicting various transcripts of $M U C 3 A(\mathbf{b})$ and $M U C 3 B(\mathbf{c})$. White and gray boxes indicate coding and non-coding regions, respectively. Introns are represented by lines. Optional exons are indicated with "elbowed" lines. Epidermal growth factor (EGF)-like domains and a transmembrane domain are marked with blue and red boxes, respectively. The sequence of CEX. V" of $M U C 3 A$ includes that of
CEX. V and 172 bp of the $3^{\prime}$-side sequence of intron E. The sequence of CEX. XII corresponds to that of nucleotide (nt) 4048 to nt 4140 in AB038782. d Similarity of the deduced amino acid sequences between the carboxyl termini of the major transcripts of $M U C 3 A$ and $M U C 3 B$. Both sequences begin at the amino acids immediately downstream of the 51-bp repeats. Dark shading indicates identical amino acids, and hyphen indicates a gap inserted to optimize the alignment. The EGFlike motifs ( $E G F 1$ and $E G F 2$ ) and the putative transmembrane regions $(T M)$ are underlined. The potential $\mathrm{N}$-glycosylation sites are indicated in italics 


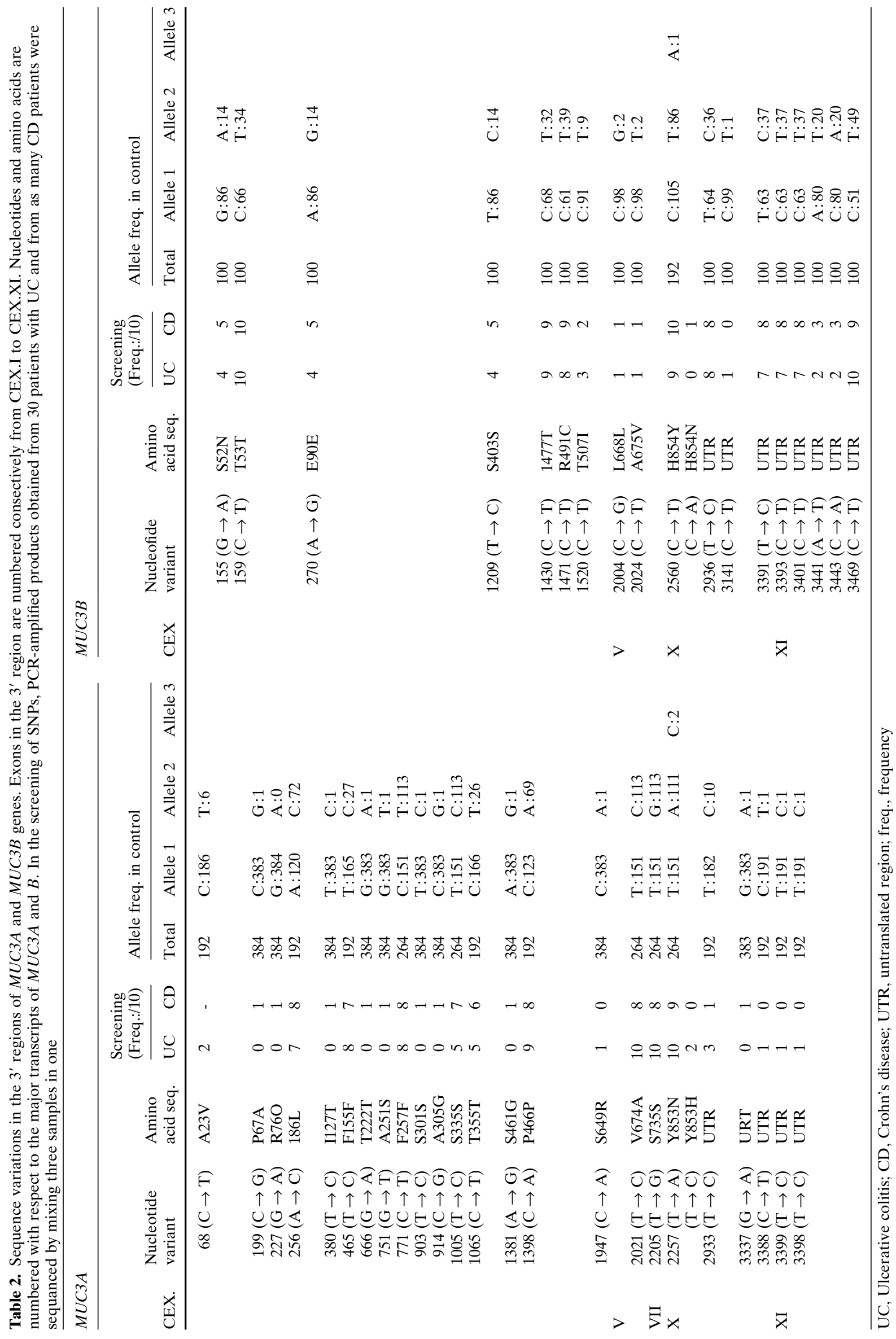


Table 3. ASO probes for single nucleotide polymorphisms

\begin{tabular}{lll}
\hline Allele & Sequence $\left(5^{\prime}\right.$ to $\left.3^{\prime}\right)$ & $\begin{array}{l}\text { Discriminatory } \\
\text { temperature }\left({ }^{\circ} \mathrm{C}\right)\end{array}$ \\
\hline $771 \mathrm{C}$ & TCCAGTGTTCTCCACTACC & 66 \\
$771 \mathrm{~T}$ & TCCAGTGTTTCCACTACC & 64 \\
$1005 \mathrm{~T}$ & CCTGCCTCTCCCACTGA & 64 \\
$1005 \mathrm{C}$ & CCTGCCTCCCCCACTGA & 66 \\
$2021 \mathrm{C}$ & CCAGGATGCGAACAGCT & 62 \\
$2021 \mathrm{~T}$ & CCAGGATGTGAACAGCT & 60 \\
$2205 \mathrm{~T}$ & CACGTCTGGGGTGGAC & 66 \\
$2205 \mathrm{G}$ & CACGTCGGGGGTGGAC & 68 \\
$2557 \mathrm{~A}$ & AATTTCAATGTGGCCTTG & 64 \\
$2557 \mathrm{C}$ & AATTTCCATGTGGCCTTG & 64 \\
$2557 \mathrm{~T}$ & AATTTCTATGTGGCCTTG & 64 \\
\hline
\end{tabular}

ASO, allele-specific oligonucleotide

identified by a nationwide survey, and medical records were reviewed for all affected siblings to confirm the diagnosis. Table 3 shows the sequences of oligonucleotide probes utilized in the genotyping at five polymorphic sites (nt 771, 1005, 2021, 2205, and 2557 of MUC3A: Table 2) where we found associations with familial CD. PCR amplifications for the genotyping were done by primer sets AF8/ABR6, AF9/ BR5, AF3/ABR7, ABF2/AR3 and AF7/ABR1, respectively. The PCR conditions were $95^{\circ} \mathrm{C}$ for $5 \mathrm{~min}$, followed by 35 cycles of $94^{\circ} \mathrm{C}$ for $30 \mathrm{~s}, 57^{\circ} \mathrm{C}$ for $30 \mathrm{~s}$ for genotyping at $\mathrm{nt}$ 771 and $2557\left(55^{\circ} \mathrm{C}\right.$ for $30 \mathrm{~s}$ for all others), and $72^{\circ} \mathrm{C}$ for 1 min for nt 2557 (for 30s for all others). In ASO hybridization analyses PCR-amplified DNAs were spotted onto Biodyne A nylon membranes (Pall corporation, East Hills, NY, USA) and UV-crosslinked. Oligonucleotide probes were end-labeled with $\gamma$-32P-dATP, using T4 polynucleotide kinase (Toyobo; Sambrool et al. 1989), and hybridized to the membranes at $42^{\circ} \mathrm{C}-50^{\circ} \mathrm{C}$ in a solution containing $6 \times$ standard saline citrate (SSC), $0.5 \%$ SDS, $100 \mu \mathrm{g} / \mathrm{ml}$ salmon sperm DNA, $2 \times$ Denhardt"s solution, and $50 \mathrm{mM}$ Tris- $\mathrm{HCl}$ ( $\mathrm{pH} 7.4)$. High-stringency washes were done in $6 \times \mathrm{SSC}$ at the discriminatory temperatures specified for each ASO (Table 3). Data values were analyzed using a $\chi^{2}$ test.

Heterozygosity at each SNP site was estimated as $2(\mathrm{pq}$ $+\mathrm{qr}+\mathrm{rp})$, where $\mathrm{p}, \mathrm{q}, \mathrm{r}$ indicate the proportion of each allele at each SNP site $(\mathrm{p}+\mathrm{q}+\mathrm{r}=1 ; \mathrm{r}=0$ except at $\mathrm{nt} 2557$ of $M U C 3 A$ and nt 2560 of $M U C 3 B$ ); for comparison of sequence diversity we estimated the nucleotide diversity as the average heterozygosity per base pair $(\pi)$.

\section{Results}

Analyses of nucleotide and amino acid sequences of the $3^{\prime}$ regions of $M U C 3 A$ and $M U C 3 B$ genes

As reported previously (Kyo et al. 1999), two distinct sets of hybridizing bands were recognized in the Southern analysis using the clone 51R as a probe (Fig. 1a). These bands were also detected with clones 3TR-1, 3TR-2, or 3TR-3, suggesting that the downstream regions of the two 51-bp repeats share high homology with each other. However, only the smaller set of bands was detected with clone $1125 \mathrm{D}$, and a quite different band, of approximately $16 \mathrm{~kb}$ in size, was detected with clone SUR (Fig. 1a), indicating that the 1125bp repeat belongs to $M U C 3 A$ and the $177-$ bp repeat to $M U C 3 B$. Based on the expected high homology between the unique regions of these two genes, we amplified and analyzed these sequences, using $P v u l l-d i g e s t e d$ genomic DNA fragments of $10-15 \mathrm{~kb}$ or of $20-40 \mathrm{~kb}$ in size as PCR templates and common primers constructed on the basis of the reported sequence (Gum et al. 1997). The size of the amplified products was $2421 \mathrm{bp}$ in $M U C 3 A$ and $2463 \mathrm{bp}$ in $M U C 3 B$. The sequence of $M U C 3 A$, compared with that of $M U C 3 B$, had a three-base deletion of the nucleotides ACA in CEX. I and a 39-base deletion in intron B (Fig. 1b and Fig. 3a), and these deletions were observed irrespective of the alleles we reported (Kyo et al. 1999). The similarity of the nucleotide sequences of the two amplified products was $94.8 \%$ and that of the exonic sequences reached $95.8 \%$, and the sequence differences between CEX. I of $M U C 3 A$ and that of $M U C 3 B$ enabled us to construct RACE primers specific to each gene. We conducted four rounds of RACE reactions for each of $M U C 3 A$ and $M U C 3 B$; the compiled nucleotide sequences of $M U C 3 A$ and $M U C 3 B$ are demonstrated in Fig. 3. The analysis of splicing variants (Fig. 2) showed that the sequences obtained in RACE reactions were those of the major transcripts in both $M U C 3 A$ and $M U C 3 B$ and in these transcripts, the unique sequences downstream of the repetitive domains of $M U C 3 A$ and $M U C 3 B$ consist of 3808-bp and 3941-bp nucleotides that encode 877- and 878-residue peptides, followed by $3^{\prime}$ untranslated regions of $1177 \mathrm{bp}$ and $1307 \mathrm{bp}$, respectively. The nucleotide and deduced amino acid sequences matched $94.1 \%$ and $94.9 \%$, respectively, and each of the deduced amino acid sequences revealed a large extracellular domain (779 and 780 amino acids of $M U C 3 A$ and $M U C 3 B$, respectively), a transmembrane domain of 23 amino acids, and a cytoplasmic tail of 75 amino acids (Fig. 2d). Comparison of the PCR-amplified genomic sequences with the RT-PCR products revealed 11 exons in the $3^{\prime}$ regions of $M U C 3 A$ and MUC3B spanning 8912 bp and 9131 bp of genomic DNA, respectively. The degree of sequence similarity between the two genomic sequences reached $91.3 \%$. The sequence which was reported as that of 3 ' region of " $M U C 3$ " (Gum et al. 1997) corresponds to that of $M U C 3 A$ in our study, although there were several errors (deletions, insertions, and substitutions) in the reported sequence. In that report, the sequence of CEX. III involved in introns and stop codon appeared in CEX. IV (Fig. 1b), which led to the conclusion that "MUC3" is a secretory mucin. Recently, Williams et al. (1999a) reanalyzed the cDNA structure of the 3 ' region of "MUC3", by conducting RT-PCR with primers constructed on the basis of the reported sequence, and they reported that "MUC3" encodes a transmembrane mucin. The sequence they reported is identical to the partial cDNA sequence of the $3^{\prime}$ region of $M U C 3 A$ in our study. Crawley et al. (1999) recently reported the genomic structure of the $3^{\prime}$ region of " $M U C 3$ " (now $M U C 3 A$ ) correcting errors in the sequence they once reported. The sequence of $M U C 3 A$ in 
a

MUCBA CEX.

MUC3A ACCTGTAACC CCATCTTCTC TGAGTACAGA

MUCBB ACCTTCATCC CCATCTTCTIITGAGTACAGA

\begin{tabular}{l|l} 
MUCBA & GCACTTCATT \\
MUC3B & GCACTTCATT
\end{tabular}

GACTACAACC ACAGACTTTC

CCTCTATACC

CACTGATAT
CACTGATAT

$A G$ T T A $A C$
$A \in G T$

A AGT TCAGAA

ACCTCATCCC

TTGTGGGCAC

CACCTCTCCC

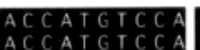

MUC3A TCATCTTCTC
MUC3B TCATCTTCIT

MUC3A GACCCTCAGA AT TACTGAGA ACACCCCAAT MUC

MUC3A AGACCCCTCC TGTACTGACG TCAGCCACTG MUC3

MUC3

MUC3B

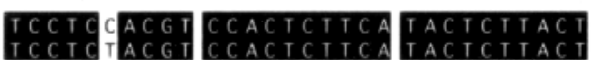

CCATCAACAG
CCATCAACAG

C C T T G AGCA

GA T C G

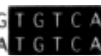

ACATCACAGG

TICCTATTCO

MUC $3 A$

MUC 38

TAGCACACAT
IAGCACACAT

TCCTCCACC
TCC TCCACC

TC CAAACAA
ITCAAACAA

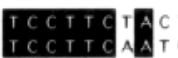

$\begin{array}{llll}C & C & C & T \\ C & C & C & T\end{array}$

ATTGC
TT T G

$A A A C T T C A C T$
$A A A C T T C A C T$

CACATCTACA
CACATCTACA

A G T G A T T CA 637

мисза

мUС 38

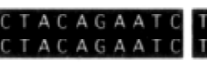

TT T C ACTAG

GGAAG TACG
GGAAG TACG

CTACAAATGC
CTACAAATG A

AATCTIGAC T
AATCIIGAC I T I T

\begin{tabular}{l} 
TC I I I I A A I A \\
IC T T T T TAG TA \\
\hline
\end{tabular}

CCATCATCTE
CCATCATCTG

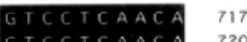

MUC3A CCCACTATTA
MUCBB CCCACTATIA
CCCACTA

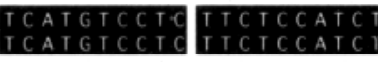

TCTGCCAGC
TCTGCCAGC

TAACTCCAC

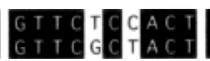

ACCATTCATT
ACCATTCATT

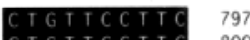

MUc3A

MUC $3 B$

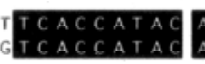

ATTTTCAGTA
ATTTTCAGTA

CAGAAAATG
CAGAAAATG

\begin{tabular}{l} 
GGGCTCCGC \\
GGGCTCCGC \\
\hline
\end{tabular}

TCTATCACAG
TCTATCACAG

CTTTCCTAG

TCTCTCTTCC
TCTCTCTTCO

\begin{tabular}{lll}
\hline TC TIGCAACTA & 877 \\
TC TTCA A T T A & 880
\end{tabular}

MUCBA CCAGCACTTC TT

NUC3B CCAGCACTIO TCGACCAGC RCCTCTCTG
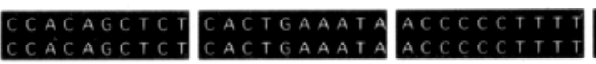

CTTATATTT
CTTATATT

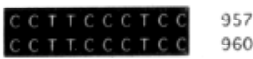

MUC3A ACCACACCCT GTCCAGGAAC TATAACAAT

MUCBB ACCACACCC T G TCCAGGAAG TATAACAATI

MUC3A CACTGAAG

MUL $3 B$

ACTGAAGC

ACTICTCCTC
ACTTCTCCTC

CCACCACTCC
CCACCACTCC

AT TAACAG T
AT TAACAGT

CTGCC?

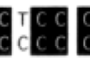

ACTGATCCA
ACTGATCCA

TGTGTTGAAA
TGTGTTGAAA

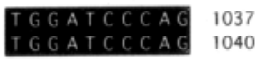

MUC3A TCAGTATCCA AACTACTCTTACTACATATATGGACACT T

MUC3A GCTTCCAGT

Fig. 3a-c. Similarity of exon sequences between the $3^{\prime}$ regions of the major transcripts of $M U C 3 A$ and $M U C 3 B$. The sequence begins at the nucleotides immediately downstream of the 51-bp repeats. Dark shading indicates identical nucleotides, and hyphens indicate gaps inserted to optimize the alignment. The EGF-like motifs (EGF1 and EGF2) and the putative transmembrane regions (TM) are underlined. The termination codons are marked with asterisks (Genbank accession number: $\mathrm{AB} 038784$ for $M U C 3 A$ and $\mathrm{AB} 038783$ for $M U C 3 B$ ). The genomic sequences are also deposited with GenBank, accession nos, AB038782 for $M U C 3 A$ and AB038781 for $M U C 3 B$ 


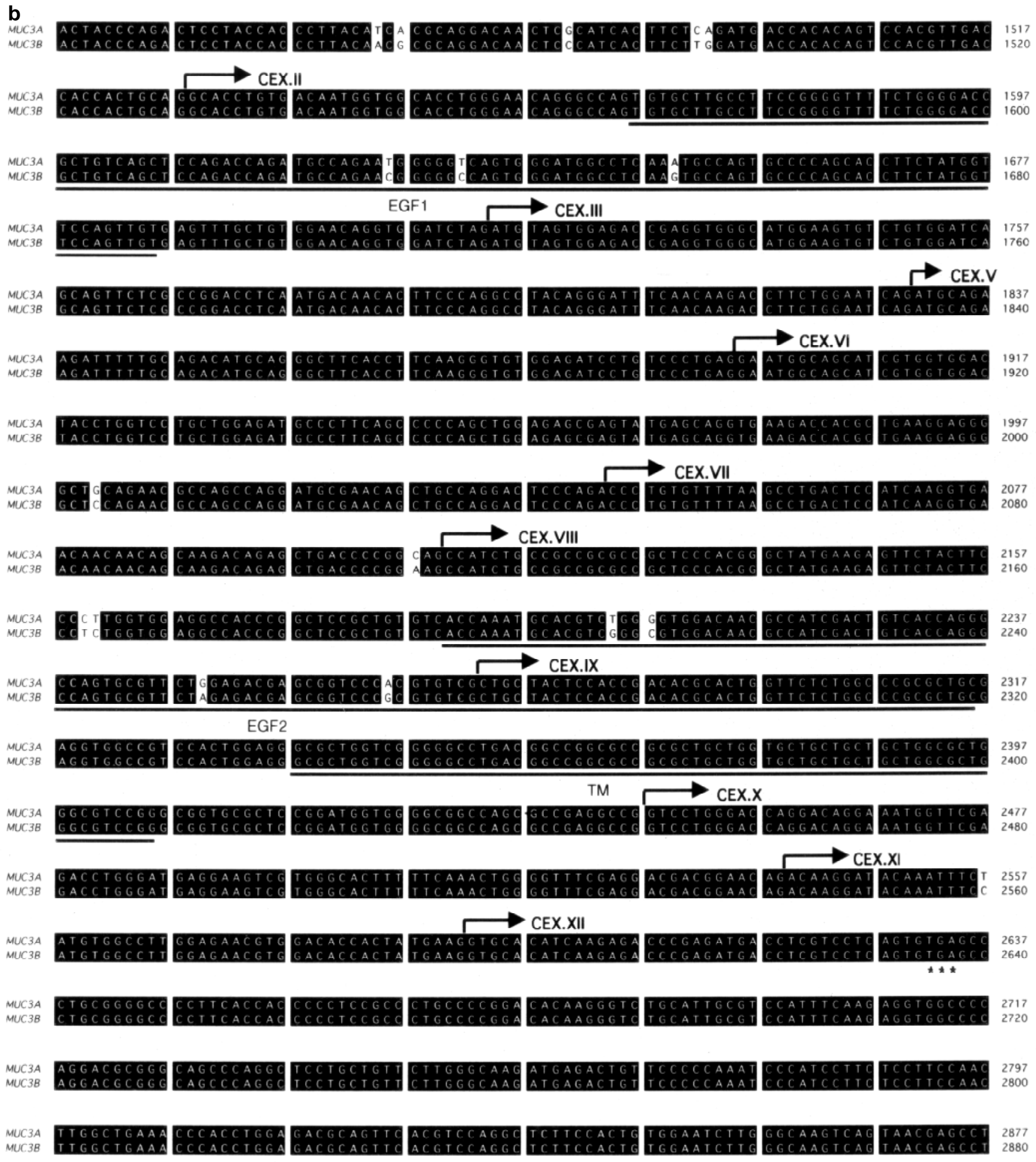

Fig. 3a-c. Continued

our study still differed from theirs in some respects; there are four nucleotide substitutions in their sequence (A, T, C, G, rather than C, C, G, C at nt 1563, 2837, 2922, 2923 of MUC3A, respectively: Fig. 3), which we did not identify in the SNP analysis.

Although each of the repetitive regions of the MUC3A and $M U C 3 B$ genes has the amino acid composition typical of a mucin gene, the deduced amino acid sequences of CEX. I of $M U C 3 A$ (and $M U C 3 B$ ) were also mucin-like, consisting of Thr $27.1 \%$ (25.5\%), Ser $21.6 \%$ (22.2\%), and Pro $11.0 \%(11.4 \%)$, accounting for $59.7 \%$ of 509 amino acids $(59.0 \%$ of 510 amino acids), and two putative $\mathrm{N}$ glycosylation sites were observed in CEX. I of each gene (Fig. 2d). The mucin-like domain was followed by two Cys- 


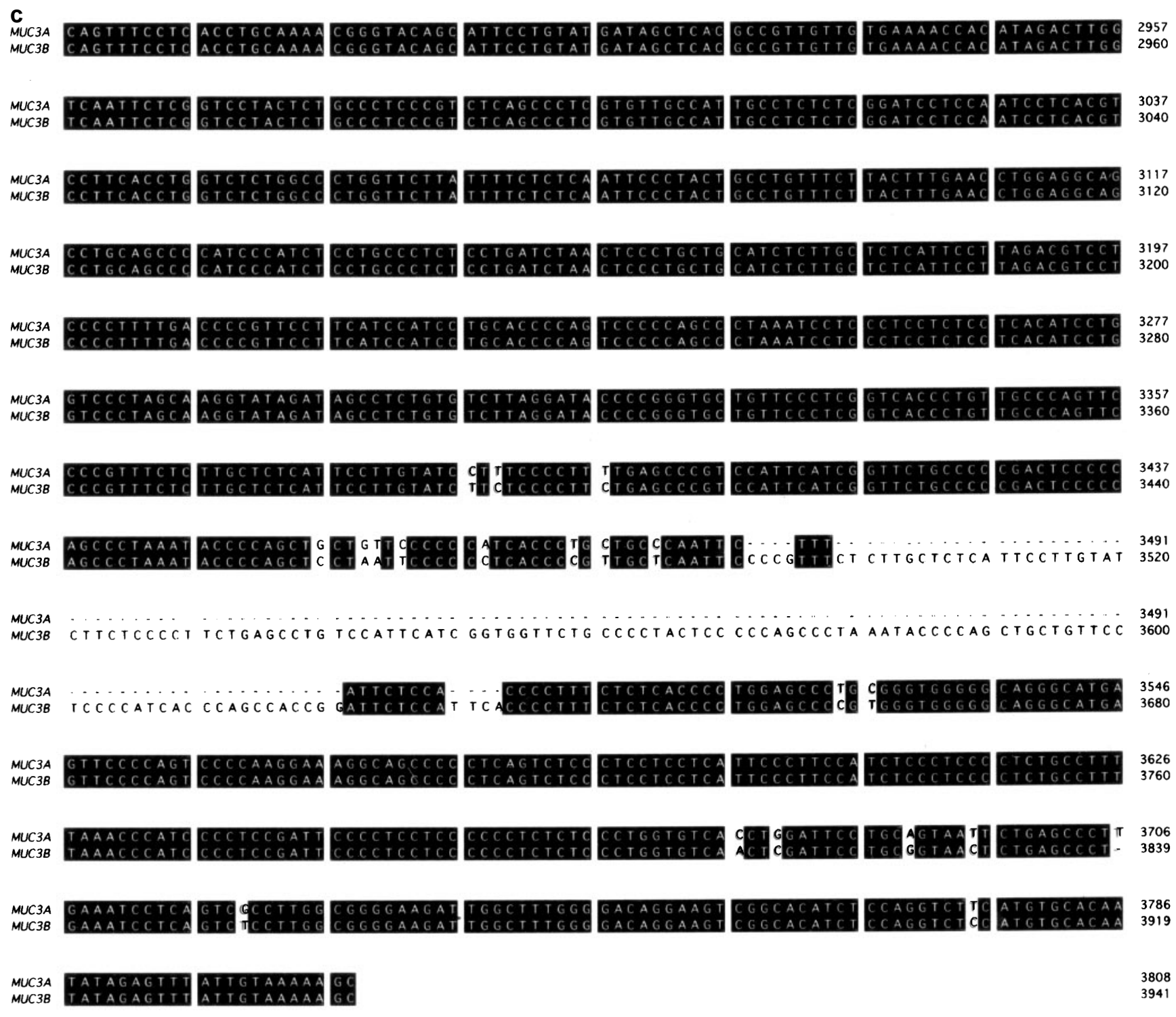

Fig. 3a-c. Continued

rich, epidermal growth factor (EGF)-like domains separated by 168 amino acids containing additional five putative $\mathrm{N}$-glycosylation sites (Fig. 2d). The first EGF-like domain (EGF1) consists of 40 amino acids (residue 523-562 for $M U C 3 A$ and 524-563 for MUC3B, Fig. 2d), and the second domain (EGF2) consists of 42 amino acids (residue 731-772 for $M U C 3 A$ and 732-773 for $M U C 3 B$, Fig. 2d) which was immediately followed by a transmembrane domain.

RT-PCR analyses of splicing variants (Fig. 2) revealed several variants with or without a transmembrane region in each of $M U C 3 A$ and $M U C 3 B$, indicating that the secretory forms of MUC3A and MUC3B mucin proteins are produced by alternative splicing rather than by proteolytic cleavage, as observed in MUC1 and MUC4 (Ligtenberg et al. 1992; Moniaux et al. 1999). Each gene has a variety of cryptic splicing sites, which resulted in novel exons including intronic sequences. All transcripts shared EGF1, and those with a transmembrane region exclusively shared EGF2.
Tissue expressions of $M U C 3 A$ and $M U C 3 B$

Northern blots, using clone $177 \mathrm{R}$ as a probe, showed expression of $M U C 3 B$ exclusively in the small and large intestines (Fig. 1d) whereas that of $M U C 3 A$, analyzed with clone $1125 \mathrm{D}$, was observed at the highest level not only in the intestines but also in heart, liver, and thymus, with lower levels in prostate and pancreas (Fig. 1c). As described previously for mucin RNAs (Debailleul et al. 1998), these messages were highly polydispersed because of shearing of the extremely large transcripts.

Identification and association analysis of SNPs

We screened for SNPs in 3697 and 3766bp of exonic sequences of the $3^{\prime}$ regions of the $M U C 3 A$ and $M U C 3 B$ genes, which consisted of 2609-bp coding and 1088-bp noncoding sequences for $M U C 3 A$, and of 2548-bp coding 
and 1218-bp non-coding sequences for MUC3B (Table 4). We identified 11 SNPs and 13 rare variants in $M U C 3 A$, and 18 SNPs in $M U C B$, corresponding to $\pi=11.2 \times 10^{-4}$ for $M U C 3 A$ and $15.5 \times 10^{-4}$ for $M U C 3 B$ (Table 4). These SNPs and rare variants are summarized in Table 2 , with the allelic frequencies observed in the control population. Despite the equal number of samples screened, rare variants were identified only in MUC3A. Among these variants, 7 variants, of $199 \mathrm{C} \rightarrow \mathrm{G}(\mathrm{P} 67 \mathrm{~A}), 380 \mathrm{~T} \rightarrow \mathrm{C}(\mathrm{I} 127 \mathrm{~T}), 666 \mathrm{G} \rightarrow \mathrm{A}$ $(\mathrm{T} 222 \mathrm{~T}), 751 \mathrm{G} \rightarrow \mathrm{T}(\mathrm{A} 251 \mathrm{~S})$, 903T $\rightarrow \mathrm{C}(\mathrm{S} 301 \mathrm{~S}), 914 \mathrm{C} \rightarrow \mathrm{G}$ $(\mathrm{A} 305 \mathrm{G})$, and $1381 \mathrm{~A} \rightarrow \mathrm{G}(\mathrm{S} 461 \mathrm{G})$, were observed in a single patient with $\mathrm{CD}$, and were also identified in only one control sample (frequency of $0.26 \%$ in 384 control alleles). The results indicate that these seven mutations occurred at the same time. Likewise, three mutations in the $3^{\prime}$ noncoding region $(3388 \mathrm{C} \rightarrow \mathrm{T}, 3390 \mathrm{~T} \rightarrow \mathrm{C}$ and $3398 \mathrm{~T} \rightarrow \mathrm{C}$ ) were identified in a single UC patient and also in a single control sample. Individuals carrying rare variants of $M U C 3 A$ were identified more often in IBD patients than in controls $(8.3 \%$ vs $2.1 \%$; Fisher's exact $P$ value $=0.0374)$.

cSNPs, particularly those that alter amino acid sequences, are most likely to influence the protein function and, thus, to be involved in complex human diseases (Cargill et al. 1999; Chakravarti 1999). A total of ten cSNPs were identified in each of the MUC3A and MUC3B genes, a frequency of one cSNP per 261 and $255 \mathrm{bp}$, respectively (Table 4). In the Southern blotting analysis we reported recently (Kyo et al. 1999), we identified three common alleles of MUC3A in the Japanese population (A7, A12 and

Table 4. Frequencies of SNPs and nucleotide diversitles of the $3^{\prime}$ regions of $M U C 3 A$ and $M U C 3 B$

\begin{tabular}{|c|c|c|c|c|}
\hline Region & $\begin{array}{l}\text { bp } \\
\text { Screened }\end{array}$ & $\begin{array}{l}\text { No. } \\
\text { SNPs }^{a}\end{array}$ & $\begin{array}{l}\text { Frequency } \\
(/ \mathrm{bp})^{\mathrm{a}}\end{array}$ & $\begin{array}{l}\text { Nucleotide } \\
\text { diversity } \\
\left(\pi \times 10^{4}\right)\end{array}$ \\
\hline \multicolumn{5}{|l|}{$M U C 3 A$} \\
\hline Coding & 2609 & $10(19)$ & $1 / 261 \quad(1 / 137)$ & 15.3 \\
\hline Noncoding & 1088 & $1(5)$ & 1/1088 (1/218) & 1.2 \\
\hline Overall & 3697 & $11(24)$ & $1 / 336$ & 11.2 \\
\hline \multicolumn{5}{|l|}{$M U C 3 B$} \\
\hline Coding & 2548 & $10(10)$ & $1 / 255 \quad(1 / 255)$ & 11.1 \\
\hline Noncoding & 1218 & $8(8)$ & $1 / 152 \quad(1 / 152)$ & 24.8 \\
\hline Overall & 3766 & $18(18)$ & $1 / 209 \quad(1 / 209)$ & 15.5 \\
\hline
\end{tabular}

${ }^{a}$ Numbers in parentheses indicate the numbers or frequencies of sequence variations which include rare variants
A14) and four in a Caucasian population (a3, a5, a6 and a9). cSNPs 771T, 1005C, 2021C, 2205G, 2557A/C were all observed almost exclusively in the A7 allele in Japanese samples $(98.6 \%$ of 510 common alleles examined) and seemed to be almost specific to A3 in Caucasian samples (99.0\% of 100 common alleles examined). Likewise, $465 \mathrm{C}$ and $1065 \mathrm{~T}$ were linked to the A12 allele, and $256 \mathrm{C}$ and 1398A were linked to A14. The allele frequency at each SNP site observed in UC or CD overall had no significant difference with that of control. However, subgroup analysis revealed significant associations of SNPs with familial CD: compared with control, familial CD cases (younger brothers or sisters of the CD-affected siblings) showed significantly increased frequency of carrying the A7-linked alleles, which were reproduced in the group of elder brothers or sisters of the $\mathrm{CD}$-affected siblings (Table 5). We examined ages at onset in CD-affected siblings to investigate whether the observed associations have practical implications for the risk of CD. Figure 4 shows the distribution of their ages at onset, with various genotypes at nucleotide 2557 in MUC3A, demonstrating a clear tendency of earlier onset in those who have nucleotides $\mathrm{A}$ or $\mathrm{C}$ at this position. The shift of onset to younger ages seems to be gene-dose dependent, and the mean age at onset is significantly younger in patients with the genotype XX (X denotes nucleotide $\mathrm{A}$ or $\mathrm{C})$

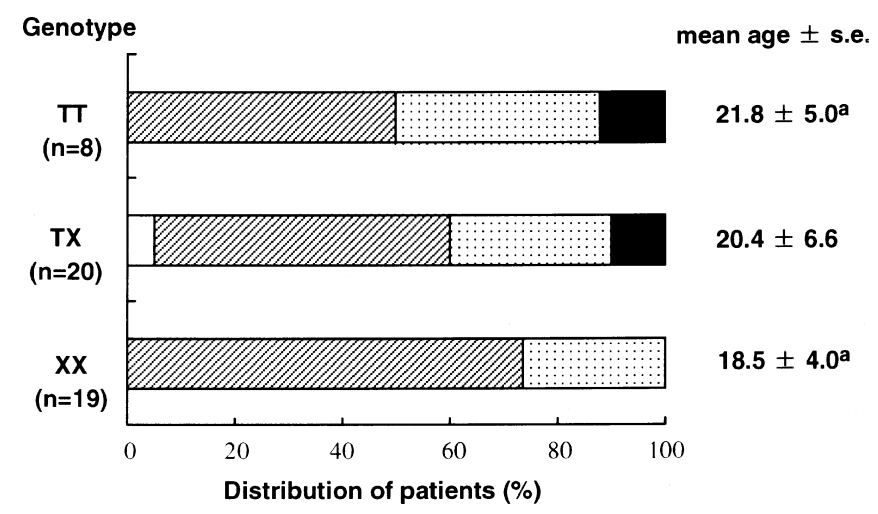

Fig. 4. Age at onset in Crohns disease-affected siblings (both elder and younger brothers or sisters) with various genotypes at nucleotide 2557 of $M U C 3 A$. X denotes nucleotide A or $\mathrm{C}$, white bars, younger than 11 years; hatched bars, from 11-20 years; dotted bars, from 21-30 years; dark bars, older than 30 years, ${ }^{a} P=0.0670$

Table 5. Genotpes at nt 2557 of $M U C 3 A$

\begin{tabular}{|c|c|c|c|c|c|c|}
\hline Genotype & Control (\%) & UC (\%) & $\mathrm{CD}^{\mathrm{a}}(\%)$ & CD-sporadic & CD-sib (1) ${ }^{\mathrm{b}}$ & CD-sib $(2)^{c}$ \\
\hline TT & $42(31.8)$ & $21(29.2)$ & $16(22.1)$ & $12(27.3)$ & $4(15.4)$ & $4(15.4)$ \\
\hline $\mathrm{AT}+\mathrm{CT}$ & $66+1(50.8)$ & $34+3(51.4)$ & $33+3(51.9)$ & $23+1(54.5)$ & $10+2(46.2)$ & $12+1(50.0)$ \\
\hline $\mathrm{AA}+\mathrm{AC}$ & $22+1(17.4)$ & $14+0(19.4)$ & $17+1(26.0)$ & $8+0(18.2)$ & $9+1(38.5)$ & $7+2(34.6)$ \\
\hline Totals & 132 & 72 & 70 & 44 & 26 & 26 \\
\hline$f(A, C)^{d}$ & 0.43 & 0.45 & 0.51 & 0.45 & $0.62 *$ & $0.60 * *$ \\
\hline
\end{tabular}

$* P=0.0132 ; * * P=0.0262$. Odds ratios for CD in familial occurence are 4.34 (XX vs TT: $\mathrm{X}$ denotes nucleotide $\mathrm{A}$ or $\mathrm{C} ; 95 \%$ confidence interval $[\mathrm{CI}], 1.70-11.10 ; P=0.0022)$ and $1.96(\mathrm{TX}$ vs TT; $95 \% \mathrm{CI}, 0.82-4.70 ; P=0.1321)$

${ }^{a} \mathrm{CD}$ includes CD-sporadic and CD-sib (1)

${ }^{\mathrm{b}} \mathrm{CD}$-sib (1) indicates younger brothers or sisters of the CD-affected siblings

${ }^{\mathrm{C}} \mathrm{CD}$-Sib (2) indicates elder brothers or sisters of the $\mathrm{CD}$-affected siblings

${ }^{\mathrm{d}} \mathrm{f}(\mathrm{A}, \mathrm{C})$, combined frequency of $\mathrm{A}$ and $\mathrm{C}$ alleles 
than in patients with the genotype TT $(P=0.0670)$. The similar nucleotide variation observed at nucleotide 2557 of $M U C 3 A$ was also observed at the corresponding position in $M U C 3 B$ (nucleotide 2560) although nucleotides $\mathrm{C}$ and A were rare in $M U C 3 A$ and $M U C 3 B$, respectively (Table 2). However, the association observed at nucleotide 2557 in $M U C A$ was not reproduced at nucleotide 2560 in $M U C 3 B$ (combined frequency of $\mathrm{A}$ and $\mathrm{C}$ alleles: $55.8 \%$ in younger brothers or sisters of CD-affected siblings vs $55.3 \%$ in control; $P=0.9507$ ), suggesting that a common variant of $M U C 3 A$ and not of $M U C 3 B$ may confer genetic predisposition to $\mathrm{CD}$.

\section{Discussion}

Twelve human mucin genes have so far been identified, but only five of them have been fully sequenced at the cDNA level. Mucin genes contain in their coding regions long stretches of variable number of tandem repeats (VNTRs) covering several kilobases, and the cloning of such genes is extraordinarily difficult, primarily because such clones show great disadvantages in propagation in bacterial cells. We could not obtain any clones of "MUC3" in the screening of the libraries of bacterial artificial chromosomes, P1-derived artificial chromosomes, or cosmids. Such clones are sometimes tolerated in yeast cells, but no clones were obtained in the screening of the yeast artificial chromosome library. We constructed a subgenomic library by cutting out Pvulldigested genomic DNA fragments of 10 to $15 \mathrm{~kb}$ in size and cloning them into lamda dashll vector to investigate the differences in sequences or structures between common and rare alleles of "MUC3" (now MUC3A), which we reported recently (Kyo et al. 1999); however, we were unable to obtain any unrecombined clones in the screening of $8 \times$ $10^{6}$ clones, which we estimated to be equal to approximately 300 genomes. The entire structure of this "gene" remains unknown, and it has also been unknown whether the 51-bp repetitive regions lie in a single gene, making an internal duplication, or whether they lie in two tandemly arrayed genes (Gum et al. 1997). We first estimated the size of "MUC3" mRNA to be approximately $17 \mathrm{~kb}$, based on the molecular mass of the "MUC3" protein precursor of $550 \mathrm{kDa}$ (van Klinken et al. 1995). This was recently confirmed by Northern blot analysis, using mRNA extracted by an improved method for large mRNA, with the size of "MUC3" mRNA estimated to be $17.5 \mathrm{~kb}$ in the gastric antrum and $17 \mathrm{~kb}$ in the colon (Debailleul et al. 1998). However, the total size of the known repetitive and unique regions far exceeds the estimated size, which led us to hypothesize that "MUC3" is composed of two genes.

We first analyzed the sequences of the $3^{\prime}$ regions just downstream of the two 51-bp repeats, and the differences observed in exonic sequences enabled us to analyze the $3^{\prime}$ terminal structures of the two genes by conducting successive RACE reactions, using primers specific to each gene. $M U C 3 A$ and $M U C 3 B$ share high homology in their 51-bp repetitive regions and in the $3^{\prime}$ regions. The recently re- ported mucin genes $M U C 11$ and MUC12 also have a very high degree of sequence similarity at their tandem repeat regions, and both are located on chromosome 7q22, the location of MUC3A and MUC3B (Williams et al. 1999b). Although the sequence of the $3^{\prime}$ region of MUC11 is unknown, that of MUC12 contains two EGF-like domains and a putative transmembrane region, like $M U C 3 A$ and $M U C 3 B$. The structural similarities among these clustering genes suggest that their $3^{\prime}$ regions may be derived from a common ancestral gene by a DNA shuffling mechanism, as suggested in secretory mucin genes clustering on $11 \mathrm{p} 15$ (Buisine et al. 1998), and that these genes on 7q22 may share some common functional features. The functional importance of these domains in MUC3A and MUC3B is supported by the presence of EGF1 in all transcripts of $M U C 3 A$ and $M U C 3 B$ and by the presence of EGF2 exclusively in all of the membrane-bound forms, and this presence of EGF2 suggests that it may function by interacting with other membrane proteins. The EGF-like motifs have the same cysteine distribution that is well conserved among functional EGF-bearing proteins involved in the adhesion, growth, differentiation, and migration of various epithelial cells (Appella et al. 1988; Engel 1989). These proteins are growth factors, receptors or receptor-like proteins, suggesting that the EGF-like regions are responsible for the interactions with a receptor or a ligand (Appella et al. 1988). The structures and the alignments of these EGF motifs observed in $M U C 3 A$ and $M U C 3 B$ are very close to those of $M U C 4$ and rat $A S G P 2$ (a rat homologue of human MUC4; Moniaux et al. 1999), both of which also encode membranebound mucins, and EGF1 of rat ASGP2 has been shown to act as a ligand for the receptor tyrosine kinase $\mathrm{p} 185^{\mathrm{neu}}$ (Carraway et al. 1999). $\mathrm{p} 185^{\mathrm{neu}}$, which shows similarity with the EGF receptor, is a rat homologue of the protooncogene c-erbB2, and is a potential modulator of cell growth. Several EGF-like peptides have so far been identified in the gut, and the structural similarities of the $3^{\prime}$ regions of $M U C 3 A$ and $M U C 3 B$ with those of MUC4 and $A S G P 2$ suggest that MUC3A and MUC3B proteins may also function as peptide growth factors. Furthermore, intestinal mucin glycoproteins are shown to promote epithelial restitution, that is, cell migration to the injured area, in the initial response to mucosal injury, both alone and in combination with trefoil factors in a synergistic manner (Kindon et al. 1995), which may be attributable to the function of those genes clustering on $7 \mathrm{q} 22$. Thus, MUC3A and MUC3B may be multifunctional cell-surface glycoproteins, like MUC1 and MUC4 (Agrawal et al. 1998a; Moniaux et al. 1999). The high level of expression of $M U C 3 A$ even in those tissues which have no known mucin secretion may indicate the importance of this protein as a cytokine.

We reported that individuals carrying one or two rare alleles of MUC3 (now MUC3A), which have an unusual number of 51-bp repeat units, have an increased risk of UC, with an odds ratio of 2.64 (95\% confidence interval [CI], 1.60-4.33; $P=0.0001$; Kyo et al. 1999). In control populations, common alleles accounted for more than $95 \%$ of total alleles, and almost all of the rare alleles accounted for less than $1 \%$, and should be considered as mutations rather than 
polymorphisms (Richards and Sutherland 1992). Some of the 51-bp repeat units are known to contain 18-bp interrupting sequences (Gum et al. 1990), which may function to stabilize the configuration of the repeat domain (Richards and Sutherland 1992) as suggested by the presence of interruptions of CAT within the (CAG)n repeat of the gene for spinocerebellar ataxia type 1 (Chung et al. 1993) and of CCT within the (CCG)n repeat of the gene for fragile $\mathrm{X}$ syndrome (Verkerk et al. 1991; Richards and Sutherland 1992). The presence of interrupting sequences and the fact that more then $95 \%$ of alleles belonged to common alleles suggest the importance of structural stability of the 51-bp repeat domain, and it seems plausible that these rare alleles could encode mucin proteins with conformational alterations. Because O-glycosylation as well as $\mathrm{N}$-glycosylation is dependent on the structure of the mucin protein (van den Steen et al. 1998), the conformational alteration of the protein could cause underglycosylation, which results in increased sensitivity for proteases, especially those secreted by intestinal bacteria (van den Steen et al. 1998; Variyam and Hoskins 1981). The degradation of the mucin protein could disrupt its epithelial barrier function, a known physical role of mucin, as well disrupting the epithelial restitution and proliferation effects mentioned above. Muc1 is one of the membrane-bound mucins expressed in the murine conjunctiva, and $M u c 1$ null mice are markedly predisposed to develop bacterial conjunctivitis, suggesting the critical protective role of mucin especially against bacteria (Kardon et al. 1999). As "MUC3" was considered to be a secretory mucin (Gum et al. 1997) when we reported the association with UC, we could not explain the dominant effect of rare alleles, because mucin protein encoded by a common allele would compensate for the function of degraded mucin; for example, by transcriptional regulation. Now that $M U C 3 A$ is shown to be a membrane-bound mucin, the increased risk of UC in those who have one or two rare alleles of MUC3A is easy to understand because of the limited expression of the protein within the cell membrane. Normal colonic mucin is heavily sulfated, a feature that prevents degradation by bacterial proteases, and the significant loss of mucin sulfation observed in patients with UC (Raouf et al. 1992) may also be related to the underglycosylation of MUC3A protein.

SNPs, particularly those that alter amino acid sequences, can be the etiologic cause of the person-to-person differences in disease susceptibility. To identify variants involved in the susceptibility to IBDs, we surveyed, for the identification of SNPs, the exons of the $3^{\prime}$ regions of MUC3A and $M U C 3 B$. The overall estimates of nucleotide diversities $(\pi)$ were two to four times higher in $M U C 3 A$ and three to five times higher in $M U C 3 B$ than those observed in other studies (Chakravarti 1999; Cargill et al. 1999). A number of factors may contribute to the high level of diversities: (i) the presence of long stretches of repeated sequences (Chakravarti 1998), (ii) local recombination frequencies (Begun and Aquadro 1992; Nachman et al. 1998), and (iii) gene conversion events between $M U C 3 A$ and $M U C 3 B$, as suggested by the similar sequence variations observed in the two genes (Table 2). Using these SNPs in the association study, we found that A7-linked variants of $M U C 3 A$ may confer genetic predisposition to $\mathrm{CD}$. Among the polymorphisms which were associated with CD, 2557T (853Y) gives a YVAL motif in the cytoplasmic tail (at residue 853-856 of MUC3A: Fig. 2d) which is similar to specific motifs recognized by SH-2 domain-containing proteins (Songyang et al. 1994). MUC12 also contains a similar motif (YNNF sequence in the cytoplasmic tail (Williams et al. 1999b), suggesting that cell signaling via SH-2-domain-containing proteins may be a common feature of the mucin proteins encoded by those genes clustering on $7 \mathrm{q} 22$. Thus, the $M U C 3 A$ allele with this tyrosine residue may show a protective effect against $\mathrm{CD}$ by this signal transduction. The association was observed only in familial $\mathrm{CD}$, but not in $\mathrm{CD}$ overall, suggesting that both genetic and environmental factors are involved in the risk for the disease occurrence, and that there is a strong environmental effect particularly in the occurrence of sporadic CD. CD-affected siblings could share some of the major and minor susceptibility genes, and the A7-linked allele of MUC3A may act in combination with the major determinant gene for disease occurrence and its earlier onset. We cannot rule out completely the possibility that the association may result from linkage disequilibrium with another intragenic polymorphism on the $\mathrm{A} 7$ allele or another gene near MUC3A that confers susceptibility to $\mathrm{CD}$. The latter possibility, however, is not plausible considering the clear tendency of the shift of onset to younger ages and the high frequencies of the minor alleles. As the relative frequency of each allele reflects, on average, its time of origin, the high frequencies of minor alleles indicate the long duration (more than 10,000 years; Chakravarti, 1999) since the occurrence of mutations at these sites. This is supported by the presence of these variations in Caucasian samples, suggesting that these mutations occurred before the differentiation of the Asian and the Caucasian populations. The extent of linkage disequilibrium at this locus is expected to be small because of the expected long duration, because the occurrence of these mutations and the high value of the nucleotide diversity $(\pi)$ suggest frequent occurrence of meiotic recombination at this locus. Thus, it is not likely for another gene near $M U C 3 A$ to show linkage disequilibrium with such a clear tendency to shift the onset to younger ages. We identified IBD patients with one or more mutations in the $3^{\prime}$ region of $M U C 3 A$, and the frequency of individuals with mutations was significantly higher in IBD patients than in controls. As for the mutations in the coding region, one patient with $\mathrm{CD}$ had seven mutations in CEX. I of $M U C 3 A$, and five of them altered the amino acid sequences. Other mutations in the coding region also altered the amino acid sequences and resulted in charge differences. These mutations or rare variants are typically recent in origin, with populationspecificity, lower survival, and stronger selection pressure, and are likely to have a direct impact on the protein function (Cargill et al. 1999; Chakravarti 1999; Halushka et al. 1999), which could bear on susceptibility to IBDs, particularly to $\mathrm{CD}$. Thus, both common and rare variants that are likely to influence the function of MUC3A mucin protein may be involved in the susceptibility to $\mathrm{CD}$. 
In this study, we demonstrated that distinct variants of $M U C 3 A$ may be involved in the occurrence of $\mathrm{UC}$ and $\mathrm{CD}$. cSNPs and mutations that alter amino acid sequences of the $3^{\prime}$ region of $M U C 3 A$ could probably influence the function of this mucin protein, which would, in turn, cause increased susceptibility to $\mathrm{CD}$. Rare variants of $M U C 3 A$, which have an unusual number of 51-bp repeat units, could have a defect in the barrier function of this mucin protein and would confer genetic predisposition to UC. Various genetic and environmental factors could be related to the risk of IBDs, and discovering a susceptibility gene in such a multifactorial disorder will not only elucidate the molecular basis of the pathogenesis but will aid in the investigation of environmental factors. The identification of common environmental factors in those who have a common genetic factor will, in turn, help genetically susceptible people to prevent development of the disease by avoiding the environmental triggers, and may also offer a new strategy for the treatment of IBDs.

\section{References}

Agrawal B, Gendler SJ, Longenecker BM (1998a) The biological role of mucins in cellular interactions and immune regulation: prospects for cancer immunotherapy. Mol Med Today 4:397-403

Agrawal B, Krantz MJ, Reddish MA, Longenecker BM (1998b) Cancer-associated MUC1 mucin inhibits human T-cell proliferation, which is reversible by IL-2. Nat Med 4:43-49

Appella EA, Weber IT, Blasi F (1998) Structure and function of epidermal growth factor-like regions in proteins. FEBS Lett 231:1-4

Begun DJ, Aquadro CF (1992) Levels of naturally occurring DNA polymorphism correlate with recombination rates in $D$. melanogaster. Nature 356:519-520

Buisine MP, Desseyn JL, Porchet N, Degand P, Laine A, Aubert JP (1998) Genomic organization of the $3^{\prime}$-region of the human MUC5AC mucin gene: additional evidence for a common ancestral gene for the 11p15.5 mucin gene family. Biochem J 332:729-738

Buisine MP, Desreumaux P, Debailleul V, Gambiez L, Geboes K, Ectors N, Delescaut MP, Degand P, Aubert JP, Colombel JF, Porchet N (1999) Abnormality in mucin gene expression in Crohn's disease. Inflamm Bowel Dis 5:24-32

Cargill M, Altshuler D, Ireland J, Sklar P, Ardlie K, Patil N, Lane CR, Lim EP, Kalyanaraman N, Nemesh J, Ziaugra L, Friedland L, Rolfe A, Warrington J, Lipshutz R, Daley GQ, Lander ES (1999) Characterization of single-nucleotide polymorphisms in coding regions of human genes. Nat Genet 22:231-238

Carraway KL III, Rossi EA, Komatsu M, Price-Schiavi SA, Huang D, Guy PM, Carvajal ME, Fregien N, Carraway CA, Carraway KL (1999) An intramembrane modulator of the ErbB2 receptor tyrosine kinase that potentiates neuregulin signaling. J Biol Chem 274:52635266

Chakravarti (1998) It's raining SNPs, hallelujah? Nat Genet 19:216217

Chakravarti A (1999) Populatiopn genetics - making sense out of sequence. Nat Genet 21:56-60

Chung MY, Ranum LPW, Duvick LA, Servadio A, Zoghbi HY, Orr HT (1993) Evidence for a mechanism predisposing to intergenerational CAG repeat instability in spinocerebellar ataxia type 1. Nat Genet 5:254-258

Crawley SC, Gum JR Jr, Hicks JW, Pratt Ws, Aubert JP, Swallow DM, Kim YS (1999) Genomic organization and structure of the 3' region of human MUC3: alternative splicing predicts membrane-bound and soluble forms of the mucin. Biochem Biophys Res Commun 263:728-736

Debailleul V, Laine A, Huet G, Mathon P, d'Hooghe MC, Aubert JP, Porchet N (1998) Human mucin genes MUC2, MUC3, MUC4,
MUC5AC, MUC5B, and MUC6 express stable and extremely large mRNAs and exhibit a variable length polymorphism; an improved method to analyze large mRNAs. J Biol Chem 273:881-890

Engel J (1989) EGF-like domains in extracellular matrix proteins: localized signals for growth and differentiation? FEBS Lett 251:1-7

Gum JR, Hicks JW, Swallow DM, Lagace RL, Byrd JC, Lamport DTA, Siddiki B, Kim YS (1990) Molecular cloning of a novel human intestinal mucin gene. Biochem Biophys Res Commun 171:407-415

Gum JR Jr, Ho JJL, Pratt WS, Hicks JW, Hill AS, Vinall LE, Roberton AM, Swallow DM, Kim YS (1997) MUC3 human intestinal mucin: analysis of gene structure, the carboxyl terminus, and a novel upstream repetitive region. J Biol Chem 272:26,678-26,686

Halushka M, Fan JB, Bentley K, Hsie L, Shen N, Weder A, Cooper R, Lipshutz R, Chakravarti A (1999) Patterns of single-nucleotide polymorphisms in candidate genes for blood-pressure homeostasis. Nat Genet 22:239-247

Housman D, Ledley FD (1998) Why pharmacogenomics? Why now? Nat Biotechnol 16:492-493

Kardon R, Price RE, Julian, J, Lagow E, Tseng SC, Gendler SJ, Carson DD (1999) Bacterial conjunctivitis in Muc1 null mice. Invest Ophthalmol Vis Sci 40:1328-1335

Kindon H, Pothoulakis C, Thim L, Lynch-Devaney K, Podolsky DK (1995) Trefoil peptide protection of intestinal epithelial barrier function: cooperative interaction with mucin glycoprotein. Gastroenterology 109:516-523

Kyo K, Parkes M, Takei Y, Nishimori H, Vyas P, Satsangi J, Simmons J, Nagawa H, Baba S, Jewell D, Muto T, Lathrop GM, Nakamura Y (1999) Association of ulcerative colitis with rare alleles of the human intestinal mucin gene, MUC3. Hum Mol Genet 8:307-311

Ligtenberg MJ, Kruijshaar L, Buijs F, van Meijer M, Litvinov SV, Hikens J (1992) Cell-associated episialin is a complex containing two proteins derived from a common precursor. J Biol Chem 267:61716177

Moniaux N, Nollet S, Porchet N, Degand P, Laine A, Aubert JP (1999) Complete sequence of the human mucin MUC4: a putative cell membrane-associated mucin. Biochem J 338:325-333

Nachman MW, Bauer VL, Crowell SL, Aquqdro CF (1998) DNA variability and recombination rates at X-linked loci in humans. Genetics 150:1133-1141

Nickerson DA, Tobe VO, Taylor SL (1997) PolyPhred: automating the detection and genotyping of single nucleotide substitutions using fluorescence-based resequencing. Nucleic Acids Res 25:2745-2751

Orholm M, Munkholm P, Langholz E, Nielsen OH, Sorensen TIA, Binder V (1991) Familial occurrence of inflammatory bowel disease. N Engl J Med 324:84-88

Raouf AH, Tsai HH, Parker N, Hoffman J, Walker RJ, Rhodes JM (1992) Sulphation of colonic and rectal mucin in inflammatory bowel disease: reduced sulphation of rectal mucus in ulcerative colitis. Clin Sci 83:623-626

Richards RI, Sutherland GR (1992) Dynamic mutations: a new class of mutations causing human disease Cell 70:709-712

Sambrool J, Fritsch EF, Maniatis T (1989) Molecular cloning: a laboratory manual. Cold Spring Harbor Laboratory Press, Cold Spring Harbor, New York

Satsangi J, Parkes M, Louis E, Hasimoto L, Kato N, Welsh K, Terwilliger JD, Lathrop GM, Bell JI, Jewell DP (1996) Two-stage genome-wide search in inflammatory bowel disease provides evidence for susceptibility loci on chromosomes 3, 7, 12. Nat Genet 14:199-202

Songyang Z, Shoelson SE, McGlade J, Olivier P, Pawson T, Bustello XR, Barbacid M, Sabe H, Hanafusa H, Yi T, Ren R, Baltimore D, Ratnofsky S, Feldman RA, Cantley LC (1994) Specific motifs recognized by the SH2 domains of Csk, 3BP2, fps/fes, GRB-2, HCP, SHC, Syk, and Vav. Mol Cell Biol 14:2777-2785

Tysk C, Lindberg E, Jarnerot G, Floderus-Myrhed B (1988) Ulcerative colitis and Crohn's disease in an unselected population of monozygotic and dizygotic twins. A study of heritability and the influence of smoking. Gut 29:990-996

Tysk C, Riedesel H, Lindberg E, Panzini B, Podlsky D, Jarnerot G (1991) Colonic glycoproteins in monozygotic twins with inflammatory bowel disease. Gastroenterology 100:419-423

van den Steen P, Rudd PM, Dwek RA (1998) Concepts and principles of O-linked glycosylation. Crit Rev Biochem Mol Biol 33:151-208

van Klinken BJ, Oussoren E, Weenink JJ, Strous GJ, Buller HA, Dekker J, Einerhand AW (1995) The human intestinal cell lines 
Caco-2 and LS174T as models to study cell-type specific mucin expression. Glycoconj J 13:757-768

van Klinken BJW, van Dikken TC, Oussoren E, Buller HA, Dekker J, Einerhand AWC (1997) Molecular cloning of human MUC3 cDNA reveals a novel 59 amino acid tandem repeat region. Biochem Biophys Res Commun 238:143-148

Variyam EP, Hoskins LC (1981) Mucin degradation in human colon ecosystems. Degradation of hog gastric mucin by fecal extracts and fecal cultures. Gastroenterology 81:751-758

Verkerk AJ, Pieretti M, Sutcliffe JS, Fu YH, Kuhl DP, Pizzuti A, Reiner O, Richards S, Victoria MF, Zhang F, Eussen BE, van Ommen GJB, Blonden LAJ, Riggins GJ, Chastain JL, Kunst CB,
Galjaard H, Caskey CT, Nelson DL, Oostra BA, Warren ST (1991) Identification of a gene $(F M R-1)$ containing a CGG repeat coincident with a breakpoint cluster region exhibiting length variation in Fragile X syndrome. Cell 65:95-914

Williams SJ, Munster DJ, Quin RJ, Gotley DC, McGuckin MA (1999a) The MUC3 gene encodes a transmembrane mucin and is alternatively spliced. Biochem Biophys Res Commun 261:83-89

Williams SJ, McGuckin MA, Gotley DC, Eyre HJ, Sutherland GR, Antalis TM (1999b) Two novel mucin genes down-regulated in colorectal cancer identified by differential display. Cancer Res 59:4083-4089 